\title{
ARTICLES
}

\section{REVERSE INCORPORATION OF STATE CONSTITUTIONAL LAW}

\author{
JOSEPH BLOCHER ${ }^{*}$
}

\begin{abstract}
State supreme courts and the United States Supreme Court are the independent and final arbiters of their respective constitutions, and may therefore take different approaches to analogous issues under those constitutions. Such issues are common because the documents were modeled after one another and contain many of the same guarantees. In answering them, state courts have, as a matter of practice, generally adopted federal constitutional doctrine as their own. Federal courts, by contrast, have largely ignored state constitutional law when interpreting the federal Constitution. In McDonald v. City of Chicago, to take one recent and high-profile example, the Court declined to adopt the state courts' near-unanimous conclusion that the proper standard of review for regulations of the "individual" right to keep and bear arms is a form of "reasonableness” review.

In an age of growing international comparativism, this lack of intranational borrowing is striking, especially since state constitutions served as the template for the federal Constitution and generally protect

* Assistant Professor, Duke Law School; B.A. 2001, Rice University; M.Phil. 2003, Cambridge University; J.D. 2006, Yale Law School. Many thanks to Sara Beale, James Boyle, Curtis Bradley, Kathy Bradley, Josh Chafetz, Mike Dorf, James Gardner, Lisa Griffin, Laurence Helfer, Johanna Kalb, Marin K. Levy, William Marshall, Jed Purdy, Judith Resnik, Barak Richman, Jim Rossi, Neil Siegel, Judge Jeffrey Sutton, Ernest Young, and workshop participants at Cornell, Duke, and Penn State law schools for their valuable feedback. Thanks also to Thomas Dominic, Christopher Moriarty, and B. Aubrey Smith for skillful research assistance.
\end{abstract}


the same rights as are found in the federal Bill of Rights. In a constitutional system that claims to be committed to federalism and respect for the states, why is it that state constitutional law has had such a slight impact on federal constitutional doctrine? This Article seeks to answer that question, and suggests that in certain circumstances federal courts should look to state constitutional law when faced with analogous federal constitutional controversies.

\section{TABLE OF CONTENTS}

I. INTRODUCTION .325

II. STATE CONSTITUTIONS AND STATE CONSTITUTIONAL

INTERPRETATION 329

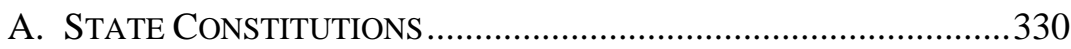

B. STATE CONSTITUTIONAL INTERPRETATION................................334

III. USING STATE CONSTITUTIONAL LAW IN FEDERAL CONSTITUTIONAL INTERPRETATION 341

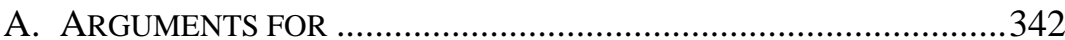

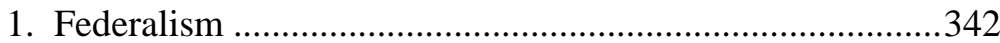

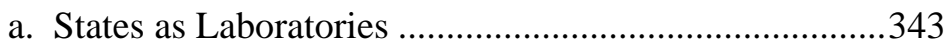

b. The Political Values of Federalism..................................344

2. An "Objective" Measure of Current Constitutional

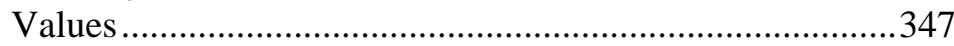

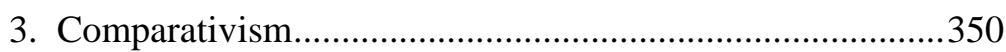

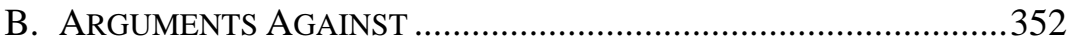

1. Conflicts with Originalism, Textualism, and Positivism....352

2. The "Political" Nature of State Constitutional Law ............355

a. State Constitutions Are Too Easily Amended ................355

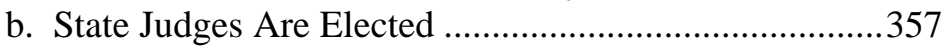

3. The Impossibility or Unhelpfulness of Comparison ............358

a. State Constitutions Are Too Different ...........................358

b. State Constitutions Are Not Good Enough, or State and Federal Judges Are Not Up to the Task ..................358

IV. THE APPROACH IN PRACTICE ..................................................358

A. REVISITING AND ElABORATING THE THEsis: TOWARD A

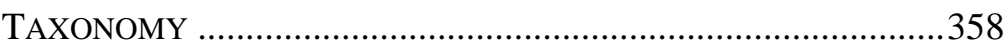

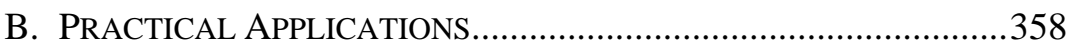

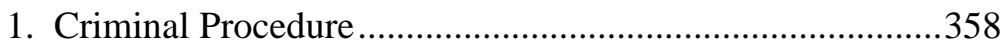

2. Substantive Due Process and Incorporation .......................358

3. The Eighth Amendment.....................................................358

C. THE SPECIAL EXAMPLE OF THE SECOND AMENDMENT.............358

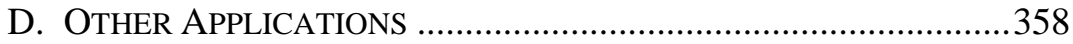




\section{INTRODUCTION}

State constitutions and the federal Constitution overlap to a considerable degree, and the courts with final interpretive authority over them often confront the same questions: Should unconstitutionally obtained evidence be admissible in court? ${ }^{1}$ Do consenting adults have a constitutional right to engage in private sexual activity? ${ }^{2}$ By what standard should the constitutionality of gun control be judged? ${ }^{3}$ In answering those questions, scholars, ${ }^{4}$ state courts, ${ }^{5}$ and even Supreme Court Justices ${ }^{6}$ have repeatedly noted that state constitutions need not be interpreted in line with the federal Constitution. And yet state courts have relied heavily-at times completely and explicitly-on federal constitutional doctrine when interpreting their own charters, even when the language, history, and intent of the latter are distinct.

The opposite, however, is not even remotely true. With a few notable exceptions, the Supreme Court ${ }^{7}$ has largely ignored state doctrine when constructing federal constitutional rules, even in areas in which the states have a widely shared and well-articulated constitutional doctrine addressing an issue on which the Supreme Court itself has never

1. See infra Part IV.B.1.

2. See infra Part IV.B.2.

3. See infra Part IV.C.

4. See, e.g., Joseph R. Grodin, Commentary, Some Reflections on State Constitutions, 15 HASTINGS CONST. L.Q. 391, 400 (1988) (“[N]either logic nor history requires that [state courts] accord state constitutional language the same meaning as the United States Supreme Court has accorded a comparable provision of the federal Constitution.”); Robert F. Williams, In the Supreme Court's Shadow: Legitimacy of State Rejection of Supreme Court Reasoning and Result, 35 S.C. L. REV. 353, 402 (1984) [hereinafter Williams, In the Supreme Court's Shadow] (criticizing the lockstep approach explained in Part II.B); Robert F. Williams, Methodology Problems in Enforcing State Constitutional Rights, 3 GA. ST. U. L. REV. 143, 171-76 (1987) (same).

5. See generally Hans A. Linde, E Pluribus-Constitutional Theory and State Courts, 18 GA. L. REV. 165 (1984) (arguing, as Oregon Supreme Court justice, for robust state constitutionalism and its significance in current federal constitutional law).

6. See generally William J. Brennan, Jr., State Constitutions and the Protection of Individual Rights, 90 HARV. L. REV. 489 (1977) [hereinafter Brennan, State Constitutions] (calling for state courts to provide broader protection of state constitutional rights than the Supreme Court was then providing for federal constitutional rights); William J. Brennan, Jr., The Bill of Rights and the States, 36 N.Y.U. L. REV. 761, 763, 777 (1961) [hereinafter Brennan, The Bill of Rights] (describing the tension between federalism and the "incorporation" doctrine, and concluding that "[i]t is reason for deep satisfaction that many of the states effectively enforce the counterparts in state constitutions of the specifics of the Bill of Rights”).

7. For simplicity's sake, I will refer to the United States Supreme Court as the "Supreme Court" or the "Court" throughout this Article. 
pronounced. The relative absence of state constitutional law as persuasive authority in federal cases is all the more striking because state legislation has received a substantial amount of scholarly and even judicial attention, at least in certain legal contexts. ${ }^{8}$ For example, the Court has found that the "clearest and most reliable objective evidence of contemporary values is the legislation enacted by the country's legislatures." ${ }^{9}$ State constitutions, by contrast, have largely been left out in the cold. Why, in a system that claims to be committed to federalism and respect for the states, are state supreme courts' interpretations of parallel constitutional provisions so thoroughly ignored? If states have a constitutionally guaranteed role as laboratories for constitutional innovation, ${ }^{10}$ why does the Court discard the lab results?

The easy answers are insufficient. The Supremacy Clause ${ }^{11}$ does not require the Supreme Court to turn a blind eye to state constitutional law. State and federal courts are the final interpreters of their respective constitutions, to be sure, but it is no more constitutionally impermissible for federal courts to borrow state doctrine than it is for state courts to rely on federal doctrine. It is also true that state constitutions differ from the federal document. But that is not enough either, unless one thinks that all comparativism is illegitimate, or that it is inappropriate for state courts to borrow federal doctrine, as they almost universally do. Of course, neither system should automatically and uncritically adopt the holdings of the other, ${ }^{12}$ but that is not the same as looking-in either direction-for persuasive authority. After all, if the Justices are comfortable citing international sources ${ }^{13}$ and even law reviews, why not also take an intranational comparative approach by drawing from sources and judges who are part of the same constitutional system?

8. See, e.g., Roderick M. Hills, Jr., Counting States, 32 HARV. J.L. \& PUB. POL’y 17, 17 (2009) ("The United States Supreme Court frequently bases federal constitutional doctrine on state law, often doing so by counting states' laws in a variety of doctrinal contexts to determine the legislative consensus among the States.”).

9. Penry v. Lynaugh, 492 U.S. 302, 331 (1989). See also Stanford v. Kentucky, 492 U.S. 361, 370 (1989) ("First among the objective indicia that reflect the public attitude toward a given sanction are statutes passed by society's elected representatives." (internal quotation marks omitted) (citing McCleskey v. Kemp, 481 U.S. 279, 300 (1987))).

10. See New State Ice Co. v. Liebmann, 285 U.S. 262, 311 (1932) (Brandeis, J., dissenting).

11. U.S. CONST. art. VI, cl. 2.

12. See supra note 4 (criticizing the lockstep approach).

13. See generally David Fontana, Refined Comparativism in Constitutional Law, 49 UCLA L. REv. 539 (2001) (surveying the practice of comparative constitutionalism and suggesting a model for its proper use); Mark Tushnet, The Possibilities of Comparative Constitutional Law, 108 YALE L.J. 1225 (1999) (similar). 
This Article represents a first effort to consider systematically the costs and benefits of using state constitutional doctrine to address problems arising under the federal Constitution. Although it is impossible (and unnecessary) to say that the approach will be useful or appropriate in all cases, the basic thesis of the Article is that federal judges confronted with federal constitutional controversies can and should draw more on the expertise of state courts that have addressed parallel controversies under their own constitutions. The aim is to describe an interpretive tool that is both normatively desirable, in that it is consistent with shared conceptions about constitutional interpretation and federalism, and practically useful, in that it is realistic about the differences between state and federal constitutions and the relative and relevant competencies of state and federal courts. The structure of the Article reflects this dual descriptive-normative goal. It begins with a description of current practice, identifies and evaluates reasons that might explain that practice, measures the thesis against past cases, and suggests how it might be used in the future.

Part II provides a brief overview of the content and interpretation of state constitutions. Although state constitutions are far more prolix than their federal counterpart, they overlap to a considerable degree with it and with one another - an unsurprising fact once one considers that the federal Constitution was patterned on state constitutions ${ }^{14}$ and that subsequent state constitutional provisions have adopted (sometimes directly) the language of the federal Constitution. That, in any event, is the conclusion that drives the major schools of state constitutional interpretation, all of which focus on the degree to which state supreme courts should or should not adopt federal constitutional law as their own. But despite state courts' heavy reliance on the Supreme Court's construction of parallel federal provisions, there has been no corresponding call for the Court to look to state constitutional law for illumination of federal problems.

Part III describes a simple thesis - that state constitutional doctrine should more often be used as persuasive authority in federal constitutional cases-and tests some arguments for and against it. Whereas incorporation means applying federal constitutional standards against the states through the Fourteenth Amendment, this type of "reverse incorporation"15 would mean applying state constitutional law against the federal government (and,

\footnotetext{
14. DONALD S. LUTZ, THE ORIGINS OF AMERICAN CONSTITUTIONALISM 97 (1998).

15. I do not mean to suggest any formal reliance on the Court's Fourteenth Amendment-based incorporation jurisprudence, or on the "reverse incorporation" effectuated in Bolling v. Sharpe, 347 U.S. 497, 500 (1954). The approach I describe could just as accurately be called "intranational borrowing” or "comparative judicial federalism.”
} 
by extension, the rest of the states, so long as the right at issue has been incorporated) through the mechanism of persuasive authority or constitutional borrowing. Part III.A considers some arguments in favor of the practice, including respect for the political values of federalism, use of the experience and expertise of state courts as laboratories for constitutional innovation, reliance on a more "objective" measure of current constitutional values, and other general benefits of constitutional comparativism. But reliance on state constitutional law is not without its drawbacks, and Part III.B considers some of the arguments against it. These include the potential for conflict with interpretive approaches like originalism and textualism, the possibility that state constitutional law is simply too different, weak, or "political" to be a useful comparator, and the practical difficulty of identifying and utilizing state constitutional law in a system in which the states differ so much from one another.

In an attempt to synthesize these arguments for and against, Part IV.A suggests a taxonomy for what kinds of cases lend themselves to borrowing state constitutional law. The normative desirability of the thesis, in other words, varies not only according to one's preferred interpretive methodology, but also with regard to the constitutional controversy at issue. In some areas, state law may simply serve as persuasive authority; in others, state constitutions have (or should have) a much stronger role. ${ }^{16}$

Part IV also demonstrates that the thesis has, in some areas of law, been descriptively accurate. First, the Supreme Court has looked to state constitutional law for guidance in criminal procedure cases, particularly with regard to the exclusionary rule and the right to counsel. Second, the Court has done so in its due process cases, by using state constitutional law to identify rights that should be considered "fundamental" and thus protected by the federal Due Process Clause or incorporated against the rest of the states through that same clause. Finally, in Eighth Amendment cases the Court has relied heavily on state law, some of it constitutional, as evidence of "evolving standards of decency." 17 The first example involves the persuasive authority of state constitutional law; the second and third examples are much closer to a mandatory reverse incorporation model that uses state law not simply to influence federal doctrine, but to define it.

16. I elaborate on this argument and address other underlying normative concerns in Joseph Blocher, What State Constitutional Law Can Tell Us About the Federal Constitution, 114 PENN. ST. L. REV. (forthcoming 2011).

17. See, e.g., Atkins v. Virginia, 536 U.S. 304, 313-17, 339-40 (2002); Stanford v. Kentucky, 492 U.S. 361, 370 (1989). 
Part IV concludes by considering McDonald v. City of Chicago, ${ }^{18}$ the most recent case involving an issue on which state constitutional law was well developed and federal constitutional law nonexistent: the appropriate standard of review by which to evaluate gun control. McDonald is a particularly interesting case study because the right it involved-the "individual" right to keep and bear arms-was constitutionally protected at the state level long before District of Columbia v. Heller ${ }^{19}$ (which itself cited state law ${ }^{20}$ ) declared it to be protected by the Second Amendment as well. ${ }^{21}$ Thus, the McDonald court was faced with the prospect of incorporating against the states a right that they already recognized, a fact the Court noted in declaring the right "fundamental" and thus subject to incorporation. But in doing so, the Court declined to adopt the constitutional doctrine that the states had unanimously embraced, one allowing for "reasonable" regulations of firearms. ${ }^{22}$ The thesis of this Article suggests that if the Court looks to state constitutions to determine the existence of a fundamental, individual right to keep and bear arms, then it should also look to state constitutional law to define the contours of that right.

\section{STATE CONSTITUTIONS AND STATE CONSTITUTIONAL INTERPRETATION}

This part gives an overview of the terrain, first describing the history and content of state constitutions and then briefly laying out some of the major issues in state constitutional interpretation.

\section{A. State Constitutions}

State constitutions are in a very real sense the root of American constitutionalism. ${ }^{23}$ In fact, "State Constitutions are the oldest things in the

18. McDonald v. City of Chicago, 130 S. Ct. 3020 (2010).

19. District of Columbia v. Heller, 554 U.S. 570 (2008).

20. See id. at 580 n.6, 583 n.7, 584-85, 590 n.13, 591, 600-04, 612-14, 629. See also id. at 64042, 648 n.10, 651 n.13 (Stevens, J., dissenting).

21. See Eugene Volokh, State Constitutional Rights to Keep and Bear Arms, 11 TEX. REV. L. \& PoL. 191, 192, 206-07 tbl.1 (2006) (noting that forty-four states recognize an individual right to bear arms).

22. See Adam Winkler, Scrutinizing the Second Amendment, 105 MicH. L. REV. 683, 687 (2007) ("Under the standard uniformly applied by the states, any law that is a 'reasonable regulation' of the arms right is constitutionally permissible.”).

23. See Randy J. Holland, State Constitutions: Purpose and Function, 69 TEMP. L. REv. 989, 989 (1996) ("State charters are the foundation of American Constitutional law."). See generally Gordon S. Wood, Foreword, State Constitution-Making in the American Revolution, 24 RUTGERS L.J. 911 
political history of America, for they are continuations and representatives of the royal colonial charters, whereby the earliest English settlements in America were created." 24 By 1783-four years before the federal Constitution was sent to them for ratification - all but one of the thenexisting states had formally adopted written constitutions, the majority of which included specific declarations of rights. ${ }^{25}$ These state constitutions not only predated their federal counterpart, but also inspired its structure and some of its most recognizable features. ${ }^{26}$

The existence of these state constitutional guarantees shaped the ratification debates, particularly the debate about the need for (and possible content of) a federal bill of rights. The fact that the federal Constitution omitted a declaration of rights when it was submitted to the states "stood in sharp contrast to the state constitutions ... virtually all of which contained explicit provisions" to that effect. ${ }^{27}$ The Federalists and Antifederalists drew opposite conclusions from that contrast. The Federalists argued, among other things, that political safeguards were sufficient to protect individual rights and that the states' bills of rights were not worthy of emulation. ${ }^{28}$ The Antifederalists responded that the federal government should hold itself to the same limitations as the states did themselves. ${ }^{29}$ When the Federalists eventually gave in and drafted a federal bill of rights, they looked to the states' bills of rights as a model. ${ }^{30}$ Thus, "Far from being

(1993) (discussing the role of state constitutions in establishing "the primary conceptions of America's political and constitutional culture").

24. Robert F. Williams, Equality Guarantees in State Constitutional Law, 63 TEX. L. REV. 1195, 1199 (1985) (quoting 1 JAMES BRYCE, THE AMERICAN COMMONWEALTH 413 (2d rev. ed. 1891)). See also McDonald v. City of Chicago, 130 S. Ct. 3020, 3066 (2010) (Thomas, J., concurring) ("After declaring their independence, the newly formed States replaced their colonial charters with constitutions and state bills of rights, almost all of which guaranteed the same fundamental rights that the former colonists previously had claimed by virtue of their English heritage.”).

25. Hans A. Linde, First Things First: Rediscovering the States' Bills of Rights, 9 U. BALT. L. REV. 379, 381 (1980).

26. LUTZ, supra note 14 , at 97.

27. Seminole Tribe of Fla. v. Florida, 517 U.S. 44, 137 (1996) (Souter, J., dissenting).

28. James Madison, for example, clearly considered the state protections problematic:

[S]ome States have no bills of rights [four states had none], there are others provided with very defective ones, and there are others whose bills of rights are not only defective, but absolutely improper; instead of securing some in the full extent which republican principles would require, they limit them too much to agree with the common ideas of liberty.

Brennan, The Bill of Rights, supra note 6, at 763 (quoting 1 ANNALS OF CoNG. 456 (1789) (Joseph Gales ed., 1834)).

29. See, e.g., Roger Sherman, A Countryman, II., in EsSAYs ON THE CONSTITUTION OF THE UNITED STATES 218, 219-20 (Paul Leicester Ford ed., 1892).

30. Holland, supra note 23, at 997 ("In fact, state Declarations of Rights were the primary origin and model for the provisions set forth in the Federal Bill of Rights."). See also LEONARD W. LEVY, ORIGINS OF THE BILl OF RIGHTS 1-11 (1999); Brennan, State Constitutions, supra note 6, at 501 
the model for the states, the Federal Bill of Rights was added to the Constitution to meet demands for the same guarantees against the new central government that people had secured against their own local officials." ${ }^{11}$ As Justice Brennan would later note, "Prior to the adoption of the federal Constitution, each of the rights eventually recognized in the federal Bill of Rights had previously been protected in one or more state constitutions." 32

James Gardner explains that "state constitutions were originally intended to be the primary vehicles for protecting the liberties of Americans, not the supplementary charters they have in many ways become." 33 And despite the addition of the federal Bill of Rights, state constitutions remained the primary guarantors of individual rights throughout most of American history. ${ }^{34}$ Over time, however, the federal Constitution displaced state constitutions as the most important source of individual rights. There are many reasons for this, but certainly much of the blame must lie with the states, which trampled rights their constitutions nominally guaranteed, and with the state judges who acquiesced. ${ }^{35}$ The

(explaining that state court decisions in the 1960s and 1970s "put[] to rest the notion that state constitutional provisions were adopted to mirror the federal Bill of Rights. The lesson of history is otherwise; indeed, the drafters of the federal Bill of Rights drew upon corresponding provisions in the various state constitutions”); Stanley Mosk, State Constitutionalism: Both Liberal and Conservative, 63 TEX. L. REv. 1081, 1081 (1985) (noting that the federal Framers "derived much of their inspiration from guarantees provided by the colonies that became the original states").

31. Linde, supra note 25, at 381. See also People v. Brisendine, 531 P.2d 1099, 1113 (Cal. 1975) ("It is a fiction too long accepted that provisions in state constitutions textually identical to the Bill of Rights were intended to mirror their federal counterpart. The lesson of history is otherwise: the Bill of Rights was based upon the corresponding provisions of the first state constitutions, rather than the reverse.”).

32. Brennan, State Constitutions, supra note 6, at 501 (citing William J. Brennan, Jr., The Bill of Rights and the States, in THE GREAT RighTS (Edmond Cahn ed., 1963)). See also Stewart G. Pollock, Adequate and Independent State Grounds as a Means of Balancing the Relationship Between State and Federal Courts, 63 TEX. L. REV. 977, 979 (1985) ("Before the enactment of the first ten amendments to the United States Constitution, fundamental liberties such as freedom from unreasonable searches and seizures were protected by state constitutions.”).

33. James A. Gardner, The Failed Discourse of State Constitutionalism, 90 MicH. L. REV. 761, 773 (1992)

34. Robert K. Fitzpatrick, Note, Neither Icarus nor Ostrich: State Constitutions as an Independent Source of Individual Rights, 79 N.Y.U. L. REV. 1833, 1836 (2004) (“As James Madison suggested during the ratification debates, for the first 175 years after the adoption of the federal Constitution, state constitutions were the primary guarantors of individual rights." (footnote omitted)).

35. See, e.g., Jeffrey M. Shaman, The Evolution of Equality in State Constitutional Law, 34 RUTGERS L.J. 1013, 1018 (2003) (“[F]or a long period of time state equality guarantees lay relatively dormant, ignored by state courts or enervated by them of their potential vitality.”). See generally RoBert M. COVER, Justice ACCused: ANTislavery AND the Judicial Process (1975) (exploring the role of antebellum judges in applying the law of slavery). But see Williams, supra note 24, at 1203 ("State constitutional equality provisions played a minor but important part in the overall process of 
Civil War and Reconstruction, of course, inaugurated a sea change from a state-based protection of individual rights toward one that was federally centered. ${ }^{36}$ The Fourteenth Amendment's declaration that all citizens of the states were also citizens of the United States, subject to the protections of its laws and Constitution, ${ }^{37}$ laid the textual foundation for this move.

As a doctrinal matter, the state-to-federal shift put into motion by the Fourteenth Amendment stumbled at first, ${ }^{38}$ but became a constitutional reality in the twentieth century through the Court's "incorporation" jurisprudence. That doctrine has bound the states to almost all of the guarantees in the federal Bill of Rights - the same list of rights that was inspired by state constitutions two centuries ago. Incorporation, however, does not require state courts to interpret their own constitutions in lockstep with the federal document. A state court can interpret its state's free speech right as being more or less expansive than the First Amendment, for example, even if the two are identically worded and even though the state itself cannot violate the federal standard. ${ }^{39}$

State courts' efforts to craft a distinct and useful state constitutional doctrine in the shadow of the federal document are discussed in more detail in the following section. Suffice it to say their task has been eased somewhat by the fact that state constitutions echo one another and the federal Constitution. ${ }^{40}$ Whether because they have copied the federal document or because it copied them, most state constitutions today contain rights guarantees that are either identical or substantially similar to those found in the federal charter. Every state has a bill of rights, ${ }^{41}$ and almost all of them reproduce in some form or another the full list of rights protected

eliminating slavery and segregation.”).

36. See McDonald v. City of Chicago, 130 S. Ct. 3020, 3028 (2010) (plurality opinion) (“The constitutional Amendments adopted in the aftermath of the Civil War fundamentally altered our country’s federal system.”).

37. U.S. CONST. amend. XIV, § 1 .

38. See Slaughter-House Cases, 83 U.S. (16 Wall.) 36, 37 (1873) (interpreting the Privileges or Immunities Clause narrowly).

39. Barry Latzer, Four Half-Truths About State Constitutional Law, 65 TEMP. L. REV. 1123, 1127 (1992) (“' $[N]$ othing in federal constitutional law prevents state courts from interpreting state law more narrowly than federal, despite the fact that they are barred [by the Supremacy Clause] from enforcing the less-protective state law.”).

40. G. Alan TARr, Understanding State Constitutions 50-55 (1998) (noting that state constitutions have borrowed extensively from one another); James A. Gardner, State Constitutional Rights as Resistance to National Power: Toward a Functional Theory of State Constitutions, 91 GEO. L.J. 1003, 1029 (2003) ("[T] the texts of the state constitutions are, at many critical points, similar or even identical to one another and to parallel provisions of the U.S. Constitution.”).

41. Gardner, supra note 40, at 1015. 
by the federal Bill of Rights. ${ }^{42}$ "For example, the constitutions of thirty-two states contain due process clauses identical to the Due Process Clauses of the ... U.S. Constitution" and "[t]he constitutions of thirty-seven states contain language identical to the Speedy Trial Clause of the federal Sixth Amendment."43 All but one state specifically protect the right to free speech, and each protects the rights to freedom of religion, to a jury trial, and from unreasonable searches and seizures. ${ }^{44}$

Although they cover the same ground as the federal Bill of Rights, nearly all state constitutions also go much further in terms of the rights they protect. Many guarantee "positive" rights_obligations on the government to provide public education, for example ${ }^{45}$ - which are unheard of in the federal system. ${ }^{46}$ But perhaps the most striking (and arguably most important) aspect of state constitutions is not their substantive content, but the ease with which they can be amended, and the corresponding frequency with which they are. ${ }^{47}$ As discussed in more detail in Part III.B.2, this feature has important implications for state constitutionalism and its relationship with federal constitutional law.

\section{B. STATE CONSTITUTIONAL INTERPRETATION}

Just as the language of federal and state constitutions has been closely

42. Robert Force, State "Bills of Rights": A Case of Neglect and the Need for a Renaissance, 3 VAL. U. L. REV. 125 app. at 165-82 (1969) (comparing state bills of rights provisions to guarantees in the federal Bill of Rights and finding substantial similarities). See also id. at 138 ("Every state provides for the protection of some or all of the rights usually referred to as First Amendment rights. All states, with varying degrees of generality or specificity, guarantee the free exercise of religion and freedom of the press."); id. at 139 ("The Second and Third Amendments are also well represented in the states .... The Fourth Amendment search and seizure warrant provisions are present in some degree in every state ...."); id. at 140 ("With the exception of the requirement of indictment by grand jury, all of the Fifth Amendment rights are well represented.... Almost all Sixth Amendment rights are also present in most of the states."); id. at 140-41 (reaching a similar conclusion with regard to the Seventh and Eighth Amendments).

43. Gardner, supra note 40, at 1029.

44. Id. at 1028. Delaware is the outlier, lacking an explicit provision protecting freedom of speech. Id. at 1028 n.118.

45. A.E. Dick Howard, State Courts and Constitutional Rights in the Day of the Burger Court, 62 VA. L. REV. 873, 917 (1976) ("Today forty-two state constitutions direct the legislature to establish a system of schools.”); Paul W. Kahn, State Constitutionalism and the Problems of Fairness, 30 VAL. U. L. REV. 459, 466 n.27 (1996) ("Every state constitution, except that of Mississippi, includes an education clause, requiring provision of free public education.”). See also Allen W. Hubsch, The Emerging Right to Education Under State Constitutional Law, 65 TEMP. L. REV. 1325, 1335-42 (1992) (discussing state constitutional educational rights).

46. See Helen Hershkoff, "Just Words": Common Law and the Enforcement of State Constitutional Social and Economic Rights, 62 STAN. L. REv. 1521, 1533-34 (2010).

47. See infra notes $174-77$ and accompanying text. 
related since the Founding, so too has the interpretation of those constitutions by federal and state judges. To take just one fundamental but often overlooked example, judicial review-sometimes characterized as the most important proposition in American constitutional law ${ }^{48}$-was a state constitutional principle before John Marshall embraced it in Marbury $v$. Madison. ${ }^{49}$ As Jeff Powell notes, "Only the eclipse of state constitutional law has led to Marbury's enthronement as the case that 'established' judicial review." 50 That eclipse has been lengthy and almost total. Despite their formal interpretive independence, state courts have generally followed the Supreme Court's lead, adopting its tests and doctrines as their own. Thus, the first question for state constitutional interpretation is an existential one: Can and should it be an enterprise independent from the Supreme Court's exposition of the federal Constitution?

As a doctrinal matter, the most important starting point is the fact that state courts have final authority in construing state charters, just as the Supreme Court bears ultimate power over the federal Constitution. ${ }^{51}$ This means that there is no legal reason why state courts must construe their own cases in "lockstep" with federal doctrine, even when the terms of the rights guarantees are identical. ${ }^{52}$ As a result, state courts can accord protection to state constitutional rights that differs from the protection given by federal courts to analogous federal rights. In practice, of course, state protections that fall below the federal floor are unlikely ever to be invoked, since states may not violate those federal rights that have been incorporated against them. But where states accord more protection than the Court has given for analogous federal rights, the federal floor might become irrelevant. ${ }^{53}$

48. See, e.g., ERWIN CHEMERINSKy, CONSTITUTIONAl LAW: PrinCiPLES AND POliCies 39 (3d ed. 2006) ("Marbury v. Madison is the single most important decision in American constitutional law.”).

49. Marbury v. Madison, 5 U.S. (1 Cranch) 137 (1803). See Howard, supra note 45, at 877 ("[L]ong before Chief Justice John Marshall decided Marbury v. Madison, state courts had begun fashioning the doctrine of judicial review.”).

50. H. Jefferson Powell, The Uses of State Constitutional History: A Case Note, 53 ALB. L. REV. 283, 294 (1989).

51. See, e.g., Michigan v. Mosley, 423 U.S. 96, 120-21 (1975) (Brennan, J., dissenting) (providing examples of state supreme court decisions interpreting state constitutions to protect individual rights); Lawrence Friedman, The Constitutional Value of Dialogue and the New Judicial Federalism, 28 HASTINGS CONST. L.Q. 93, 100 (2000) ("[S]tate supreme courts have the unquestioned, final authority to interpret their state constitutions.”).

52. See Gardner, supra note 40 , at 1030.

53. See California v. Greenwood, 486 U.S. 35, 43 (1988) ("Individual states may surely construe their own constitutions as imposing more stringent constraints on police conduct than does the Federal Constitution.”); California v. Ramos, 463 U.S. 992, 1013-14 (1983) ("It is elementary that States are 
With that basic interpretive fact in mind, it is somewhat less surprising that throughout much of American history, state constitutional interpretation was the most important game in town. When the Court (per Chief Justice Marshall) held in Barron v. Mayor of Baltimore ${ }^{54}$ that states were not beholden to the federal Bill of Rights, the only "individual rights" provisions they were bound to respect were those found in their own constitutions. Moreover, at least until the 1930s, state statutes and common law were more important than their federal equivalents. In the 1970s, Justice Brennan reminisced that in the "days of innocence" of his early law practice, "the preoccupation of the profession, bench and bar, was with questions usually answered by application of state common law principles or state statutes."55

Of course, the preeminence of state law changed in part due to the New Deal, ${ }^{56}$ as the reach of federal law grew in ways that would have been unimaginable decades earlier. But in the decades following this expansion of federal statutory law (and the "structural" constitutional law necessary to justify and sustain $i t^{57}$ ), an even more serious challenge to the centrality of state constitutional law would emerge. This was the Supreme Court's "incorporation" doctrine, which applied the guarantees of the federal Bill of Rights to the states. The process of incorporation began slowly in the 1930s, but accelerated throughout the 1960s under the Warren Court. ${ }^{58}$ This expansion of federal rights was doubtless due in part to state courts' apparent inability or unwillingness to effectuate the rights guaranteed by their own constitutions. ${ }^{59}$

free to provide greater protections in their criminal justice system than the Federal Constitution requires.”); PruneYard Shopping Ctr. v. Robins, 447 U.S. 74, 81 (1980) (noting that each state has a "sovereign right to adopt in its own Constitution individual liberties more expansive than those conferred by the Federal Constitution").

54. Barron v. Mayor of Balt., 32 U.S. (7 Pet.) 243, 250-51 (1833).

55. Brennan, State Constitutions, supra note 6, at 489.

56. See 1 Bruce Ackerman, We the People: Foundations 42-44 (1991) ("[T]he 1930's mark the definitive constitutional triumph of activist national government.”).

57. See, e.g., W. Coast Hotel Co. v. Parrish, 300 U.S. 379, 400 (1937).

58. Brennan, State Constitutions, supra note 6, at 493 ("It was in the years from 1962 to 1969 that the face of the law changed.").

59. See Linde, supra note 5, at 174; David Schuman, A Failed Critique of State Constitutionalism, 91 MicH. L. REV. 274, 280 (1992) (arguing that incorporation doctrine "resulted from the unwillingness of many state courts, particularly in the South, to use their own constitutions to protect their citizens from state overreaching”). For a contemporary observation on the issue, see Monrad G. Paulsen, State Constitutions, State Courts and First Amendment Freedoms, 4 VAND. L. Rev. 620, 642 (1951) (“Although state constitutions contain full statements of our civil liberties, ... . [o]nly occasionally do state cases concerned with freedom of press, speech, assembly and worship take a position protecting the freedoms beyond what has been required by the United States Supreme Court.”). 
Incorporation, combined with the Warren Court's expansive reading of the federal rights that were being incorporated, effectively sidelined state constitutional law. ${ }^{60}$ States could continue to read their constitutions however they pleased-many had already recognized the rights that were being incorporated against them ${ }^{61}$ —but the Supremacy Clause required them to treat the federal guarantees as a "floor" beneath which state rights could not fall. As a result, state constitutional law emerged as an independent legal force only where it exceeded the federal floor. ${ }^{62}$ And since relatively few state courts were inclined to read rights more broadly than the Warren Court, the Federal Reporter effectively displaced state constitutions. ${ }^{63}$ Any litigant with a modicum of litigation savvy knew to put federal claims front and center, meaning that state court decisions were increasingly ignored by litigants ${ }^{64}$ and scholars ${ }^{65}$ alike. And many state courts, knowing that federal rights were so expansive, tended to resolve cases on the basis of federal guarantees rather than state analogues. The result was an atrophying of state constitutional interpretation.

60. Charles G. Douglas, III, State Judicial Activism-The New Role for State Bills of Rights, 12 SUFFOLK U. L. REV. 1123, 1140 (1978) ("The federalization of all our rights has led to a rapid withering of the development of state decisions based upon state constitutional provisions."); Gardner, supra note 33, at 805 ("By far the most widely accepted explanation for the poverty of contemporary state constitutional law holds that it was marginalized by the Fourteenth Amendment incorporation doctrine.”); James A. Gardner \& Jim Rossi, Foreword, The New Frontier of State Constitutional Law, 46 WM. \& MARY L. REV. 1231, 1232-33 (2005) (noting that after the Warren Court's expansive reading of individual rights, "state constitutional law was seen, not illogically, as in some fundamental way subordinate to national constitutional law").

61. Linde, supra note 25, at 382 ("[T]he states had all these guarantees in their own laws long before the Federal Bill of Rights was applied to the states. State courts had been administering these laws, sometimes generously, more often not, for a century or more without awaiting an interpretation from the United States Supreme Court.”).

62. See Robin B. Johansen, Note, The New Federalism: Toward a Principled Interpretation of the State Constitution, 29 STAN. L. Rev. 297, 297 (1977) ("Because United States Supreme Court decisions interpreting the Bill of Rights and the 14th amendment mark the minimum guarantees of individual rights, state courts that give truly independent force to their own constitutions generally reach decisions more protective of those rights than the Supreme Court.”).

63. Force, supra note 42, at 125 (suggesting, partly in jest, "The state Bills of Rights have been superseded. No one pays any attention to them anymore; lawyers don't even cite them in their briefs now. A state constitution should be streamlined. The Bill of Rights has to go!”).

64. Linde, supra note 25, at 391 ("A generation of lawyers brought up on United States Supreme Court opinions seems literally speechless when we ask from the bench, as we sometimes do, how we should decide a constitutional question if the Supreme Court has never addressed it."); Paulsen, supra note 59, at 620 ("State court decisions and state constitutional materials are too frequently ignored by both commentator and counsel when civil liberties questions arise.”).

65. Hans A. Linde, State Constitutions Are Not Common Law: Comments on Gardner's Failed Discourse, 24 RUTGERS L.J. 927, 936 (1993) (decrying the "ingrained assumption[]” that "attention to the constitutional law of a state ... is for ambitious professors and law review editors a distinctly minor league game”). 
But if state constitutional interpretation was submerged when the Warren Court's tide rolled in, it was uncovered again when that tide rolled back out. As belief spread that the Burger Court would not read individual rights guarantees as expansively as its predecessor, state constitutional guarantees ceased being irrelevant-the federal floor had receded, and it was now possible that a state constitutional claim might succeed where its federal analogue would fail. Liberals saw their opportunity. ${ }^{66}$ Led by Justice Brennan-who called them to arms both in his opinions (usually dissents ${ }^{67}$ ) and in articles and speeches-liberals urged state courts to "step into the breach" left by the Burger Court's "contraction of federal rights and remedies on grounds of federalism." 68 The "Magna Carta" of this new movement in state constitutional interpretation was Justice Brennan's 1977 Harvard Law Review article, "State Constitutions and the Protection of Individual Rights," 69 in which he called on state courts to reclaim ground the Burger Court had allegedly given away. ${ }^{70}$ Brennan undoubtedly saw

66. It seems to be relatively well accepted that the push for expanded state constitutionalism was a liberal phenomenon. Kahn, supra note 45, at 464 ("State constitutionalism represented a kind of forum shopping for liberals.”); Johansen, supra note 62, at 299 ("Writers on both sides of the independent interpretation debate suggest that state courts are turning to their own constitutions primarily because they disagree with the growing 'conservatism' of the Burger Court.”); Earl M. Maltz, The Political Dynamic of the "New Judicial Federalism," 2 EmERGING Issues ST. CONST. L. 233, 235 (1989) ("[T]he revival of interest in state constitutionalism is generally conceded to be a reaction to the Burger Court's perceived hostility to Warren Court activism and its extension.”).

67. See, e.g., United States v. Miller, 425 U.S. 435, 454-55 (1976) (Brennan, J., dissenting); Paul v. Davis, 424 U.S. 693, 735 n.18 (1976) (Brennan, J., dissenting); Michigan v. Mosley, 423 U.S. 96, 120 (1975) (Brennan, J., dissenting) ("In light of today's erosion of Miranda standards as a matter of federal constitutional law, it is appropriate to observe that no State is precluded by the decision from adhering to higher standards under state law.”).

68. William J. Brennan, Jr., The Bill of Rights and the States: The Revival of State Constitutions as Guardians of Individual Rights, 61 N.Y.U. L. REV. 535, 548 (1986). See also Brennan Lauds State Courts for Taking Lead in Defending Rights, 18 CRIM. JUST. NEWSL., May 1, 1987, at 5. Similar voices were heard even before Warren E. Burger became Chief Justice. See, e.g., Force, supra note 42, at 126 (" $[S]$ tates in the past have played an important, although far from ideal, role in the protection of individual rights and must be prepared to play an even more important role in the future.”). Justice Brennan himself had been emphasizing these issues for years, and already in 1961 had written of the importance of state guarantees of individual rights beyond the "incorporation" doctrine, and encouraged judicial intervention and a larger role for state courts in enforcing state bills of rights. Brennan, The Bill of Rights, supra note 6, at 777-78.

69. Brennan, State Constitutions, supra note 6.

70. Stewart G. Pollock, State Constitutions as Separate Sources of Fundamental Rights, 35 Rutgers L. Rev. 707, 716 (1983) (describing Brennan's article as the "Magna Carta of state constitutional law"). See also Friedman, supra note 51, at 93 (claiming that "[t]he story of the modern state constitutionalism movement begins with [Brennan's article]”); Gardner, supra note 40, at 1031 (concluding that the "present era in state constitutional jurisprudence can be traced" to Brennan's article); Kahn, supra note 45, at 459 n.2 (referring to Brennan's article as "the starting point of a new scholarly attention to state constitutionalism"). Hans A. Linde, however, concludes that “[c]ontemporary discussion in the law reviews began ... in 1969.” Linde, supra note 5, at 175 (citing 
this as a way to expand individual rights, ${ }^{71}$ and for good reason: state constitutional doctrine will almost inevitably have a rights-expanding effect, since-at least for state constitutional rights whose federal analogues have been incorporated-state constitutional law will be irrelevant wherever it falls below the federal floor, but can always build on that floor. $^{72}$ Even so, the desire for a more robust system of state constitutional interpretation was not, and is not, confined to liberals. Many supported - and continue to support-the importance of state constitutional law on grounds that are not so outcome oriented, or which focus on principles like federalism. ${ }^{73}$ Chief Justice Burger, for example, occasionally gestured toward an expanded role for state courts. ${ }^{74}$

The degree to which state courts have answered the call to action remains debatable. Paul Kahn writes that "[a]s much as any judicial opinion [Brennan] ever wrote, this plea has influenced the development of American constitutionalism."75 This is certainly true in some sense: many state courts gave broader protection to state constitutional rights than the Burger Court did for those rights' federal analogues. ${ }^{76}$ This was most notable in the area of criminal procedure, where the Burger Court was perceived as being especially rights restrictive and some state courts responded by expanding state-level protections. ${ }^{77}$

Force, supra note 42).

71. Earl M. Maltz, False Prophet-Justice Brennan and the Theory of State Constitutional Law, 15 Hastings Const. L.Q. 429, 432 (1988) (criticizing Brennan's outcome-oriented vision of state constitutional law).

72. Id. at 433 (concluding that it is "virtually guarantee[d] that state court activism" primarily will favor liberal causes and have a liberal effect because state courts have to respect the floor set by federal rights guarantees).

73. See, e.g., Randall T. Shepard, The Maturing Nature of State Constitution Jurisprudence, 30 VAL. U. L. REV. 421, 421 (1996) ("[T]he continuing strength of this movement does not derive from a desire to continue, at the state level, the agenda of the Warren-Brennan Court. It derives from the aspiration of state court judges to be independent sources of law.").

74. See, e.g., Wisconsin v. Constantineau, 400 U.S. 433, 440 (1971) (Burger, C.J., dissenting) ("For all we know, the state courts would find this statute invalid under the State Constitution, but no one on either side of the case thought to discuss this or exhibit any interest in the subject.").

75. Paul W. Kahn, Interpretation and Authority in State Constitutionalism, 106 HARV. L. ReV. 1147, 1147 (1993).

76. TARR, supra note 40, at 165-66 (finding that between 1950 and 1969, state courts relied on state constitutions to afford greater protection than the federal Constitution in only ten cases, but that they did so in more than three hundred cases between 1970 and 1986); Brennan, supra note 68, at 549 ("[S]tate courts have responded with marvelous enthusiasm to many not-so-subtle invitations to fill the constitutional gaps left by the decisions of the Supreme Court majority.”); James N.G. Cauthen, Expanding Rights Under State Constitutions: A Quantitative Appraisal, 63 ALB. L. REV. 1183, 1201-02 (2000) (concluding that state supreme courts have, in hundreds of cases, interpreted state constitutions to provide more protection for individual liberties than similar provisions of the federal Constitution).

77. See Donald E. Wilkes, Jr., More on the New Federalism in Criminal Procedure, 63 KY. L.J. 
On the other hand, either from force of habit, mistaken belief that they were bound by the federal rules, lack of expertise, or simply because they agreed with the Burger Court's reasoning, most state courts continued to apply their own constitutional provisions in lockstep with federal analogues. ${ }^{78}$ To this day, most state courts adopt federal constitutional law as their own. ${ }^{79}$ Bowing to the nationalization of constitutional discourse, they "tend to follow whatever doctrinal vocabulary is used by the United States Supreme Court, discussed in the law reviews, and taught in the law schools." 80

As state courts struggled with the questions of when, why, and how to follow or diverge from federal doctrine, the debate launched by Justice Brennan in the pages of the Harvard Law Review began to fill other law journals with scholarly treatment of what many called the "New Judicial Federalism." That scholarship did not—and still has not ${ }^{81}$ — come anywhere near rivaling the attention lavished on the federal Constitution, but after decades in the wilderness its appearance in polite society has nonetheless been startling. The literature is too varied to summarize easily, but it is fair to say that the major question it seeks to answer is whether state courts should follow federal constitutional law when addressing state constitutional questions.

At least three major schools of thought have emerged—all of them useful both as descriptions of state courts' actual behavior and as normative accounts of what that behavior should be. The first is known as the primacy

873, 873-75 (1975); Donald E. Wilkes, Jr., The New Federalism in Criminal Procedure: State Court Evasion of the Burger Court, 62 KY. L.J. 421, 425-26 (1974).

78. Gardner \& Rossi, supra note 60, at 1233 ("[S]tate courts often acted as though they need not bother to look any further than the shared national principles embodied in the U.S. Constitution.”).

79. Craig F. Emmert \& Carol Ann Traut, State Supreme Courts, State Constitutions, and Judicial Policymaking, 16 JUST. SYS. J. 37, 47 (1992) (concluding "that much constitutional policymaking by state supreme courts involves application of national judicial policy to the states”); Fitzpatrick, supra note 34, at 1850 ("Despite ... criticism, the lockstep approach remains the most common approach to state constitutionalism.”); Michael E. Solimine \& James L. Walker, Federalism, Liberty and State Constitutional Law, 23 OHIO N.U. L. REV. 1457, 1467 (1997) ("Despite the considerable hoopla afforded a few decisions from a few states, the vast majority of state courts follow federal law when construing the liberty-protecting provisions of their own constitutions ....").

80. Linde, supra note 5, at 186.

81. See, e.g., Paul Brest, The Fundamental Rights Controversy: The Essential Contradictions of Normative Constitutional Scholarship, 90 YALE L.J. 1063, 1105 n.228 (1981) (“[D]espite the increasing activism of some courts, the state judiciary remains at the periphery of the scholars' vision.”); Jennifer Friesen, Adventures in Federalism: Some Observations on the Overlapping Spheres of State and Federal Constitutional Law, 3 WIDENER J. PUB. L. 25, 32 (1993) ("It is past the hour when state constitutional law should lose the glamour of innovation and become part of the standardized curriculum.”). 
approach, and is associated with law professor and former justice of the Oregon Supreme Court Hans Linde. Under this approach, state courts faced with state and federal constitutional claims should resolve the former first, thereby encouraging the growth of an independent and relevant body of state constitutional law. ${ }^{82}$ The second approach is called the criteria (or interstitial ${ }^{83}$ ) approach, under which "state courts assume 'the dominance of federal law and focus directly on the gap-filling potential of state constitutions." "84 Under this approach, federal constitutional law plays the lead role, with state constitutional law emerging only in certain predefined circumstances or where gaps remain to be filled. The third method is known somewhat derogatively as the lockstep approach, under which state courts interpret their constitutional provisions as having the same meaning as their federal analogues. ${ }^{85}$ This final approach is perhaps the most accurate descriptively, ${ }^{86}$ but it is nonetheless widely reviled by scholars of state constitutional law. Overlaying the discussions of these three approaches to state constitutional interpretation, as well as various permutations and iterations thereof, are sharply divergent views about whether a robust state constitutionalism is desirable, or even possible. ${ }^{87}$

The purpose of this Article is not to resolve, nor even thoroughly to explore, the debate about how state courts should interpret their own constitutions, but rather to focus on if and how federal courts should rely on those interpretations. For that debate, the relevant point is that a majorand perhaps primary-question for state constitutional law has been the degree to which state courts should rely on federal constitutional doctrine when interpreting parallel provisions of state constitutions. And yet there has been no corresponding call for federal courts to learn from the state

82. See Linde, supra note 5, at 178 ("My own view has long been that a state court always is responsible for the law of its state before deciding whether the state falls short of a national standard, so that no federal issue is properly reached when the state's law protects the claimed right.”); Hans A. Linde, Without “Due Process”: Unconstitutional Law in Oregon, 49 OR. L. REV. 125, 135 (1970) ("Claims raised under the state constitution should always be dealt with and disposed of before reaching a fourteenth amendment claim of deprivation of due process or equal protection.” (emphasis omitted)).

83. Gardner, supra note 33, at 774-75. Justin Long describes a similar approach he calls “intermittent” state constitutionalism. See Justin Long, Intermittent State Constitutionalism, 34 PEPP. L. REV. 41, 48-50 (2006).

84. Friedman, supra note 51, at 104 (quoting Developments in the Law-The Interpretation of State Constitutional Rights, 95 HARV. L. REV. 1324, 1357 (1982)).

85. Id. at 102 ("Under the lockstep approach, the state constitutional analysis begins and ends with consideration of the U.S. Supreme Court's interpretation of the textual provision at issue.”).

86. See supra note 78 and accompanying text.

87. See, e.g., Gardner, supra note 33, at 823-32 (presenting practical and normative arguments against robust state constitutionalism); Daniel B. Rodriguez, State Constitutional Theory and Its Prospects, 28 N.M. L. REV. 271, 286-300 (1998) (similar). 
courts, despite the fact that many of the benefits of constitutional borrowing would presumably flow in that direction as well. The following part considers why this asymmetry exists and whether it is justified.

\section{USING STATE CONSTITUTIONAL LAW IN FEDERAL CONSTITUTIONAL INTERPRETATION}

The overall project of this Article is to consider whether state constitutional law is, can be, and perhaps should be a useful tool for federal constitutional interpretation. Rather than suggesting a single overarching answer to that question, this part aims to consider the weighty arguments for and against such a practice.

By cataloguing positives and negatives, I do not mean to suggest that determining the appropriateness of borrowing state constitutional law is a simple matter of counting up hash marks and finding, for example, three convincing arguments in favor and only two against. Undoubtedly some arguments are more important than others. Nor by listing arguments do I mean to indicate that there are no deeper threads connecting them. To the contrary, separating the arguments is important precisely because it makes it easier to tease out those threads.

Moreover, identifying the separate arguments helps demonstrate how the use of state constitutional law as an interpretive aid fits more comfortably with some theories of federal constitutional interpretation than it does with others. For example, use of state constitutional law may be particularly germane for those who believe in "pragmatic" adjudication, ${ }^{88}$ since it provides a systematic way to take into account such practical matters as the experience and wisdom of state courts, and to a lesser degree the contemporary constitutional values of the people as a whole. For the same reasons, applying state constitutional law as an interpretive tool may be attractive to those who believe that there is a moral and ethical component to constitutional interpretation, ${ }^{89}$ or that constitutional law can

88. See Stephen Breyer, Active Liberty: INTERPREting OUR DEMOCRATIC CONSTITUTION 16 (2005); Richard A. Posner, LaW, Pragmatism, AND Democracy 385 (2003) (“[P]ragmatic analyses are connected by their common origin in an unillusioned conception of the character, motives, and competence of the participants in the governmental process, whether judges, politicians, other officials, or ordinary voters.").

89. See Lawrence G. Sager, Cool Federalism and the Life-Cycle of Moral Progress, 46 WM. \& MARY L. REV. 1385, 1391-97 (2005) (describing the system by which states' moral experimentation should be allowed and encouraged, with the federal government imposing uniformity only after principles have become generally accepted). 
and should be shaped by popular values. ${ }^{90}$ And for those who seek to interpret the Constitution in light of the "structure" it creates ${ }^{91}$ —respect for the states being one of the most important incidents of that structurerelying on states' interpretations of parallel constitutional provisions is a powerful way to respect not just the states' political branches, but their courts as well.

\section{A. ARgumentS FOR}

For simplicity's sake, the discussion here focuses on three potential benefits of using state constitutional law as persuasive authority: federalism, measuring contemporary constitutional values, and comparativism.

\section{Federalism}

It has often been said that the hallmark of American constitutionalism is the division of power between the federal government and the states. ${ }^{92}$ State constitutional law has an important and arguably underappreciated role to play in this federalist structure. ${ }^{93}$

\section{a. States as Laboratories}

There are many ways to explain and justify our commitment (whether real or imagined) to federalism. One of the most powerful, however, derives from Justice Brandeis's obligatorily quotable observation that "[i]t is one of the happy incidents of the federal system that a single courageous State may, if its citizens choose, serve as a laboratory; and try novel social and economic experiments without risk to the rest of the country." ${ }^{94}$ The

90. See Larry D. Kramer, The People Themselves: Popular Constitutionalism and JUDICIAL REVIEW 107 (2004) ("In a world of popular constitutionalism, government officials are the regulated, not the regulators, and final interpretive authority rests with the people themselves.”).

91. Charles L. Black, JR., Structure and Relationship in CONSTitutional LAW 15 (1969) ("[J]udgment is reached not fundamentally on the basis of that kind of textual exegesis which we tend to regard as normal, but on the basis of reasoning from the total structure which the text has created.”).

92. See, e.g., Rachel E. Barkow, Institutional Design and the Policing of Prosecutors: Lessons from Administrative Law, 61 STAN. L. REV. 869, 869 (2009) (describing the American system as "a government whose hallmark is supposed to be the separation of powers"); Jonathan Zasloff, The Tyranny of Madison, 44 UCLA L. REV. 795, 810 (1997) ("The separation of powers serves as the central hallmark of American constitutional structure.").

93. Henry M. Hart, Jr., The Relations Between State and Federal Law, 54 ColuM. L. REv. 489, 491 (1954) ("Nowhere is the theory and practice of American federalism more significantly revealed than in the constitutions of the states."). See also Holland, supra note 23, at 989 ("A knowledge of the origins and history of state constitutions is essential to understanding federalism in the United States.").

94. New State Ice Co. v. Liebmann, 285 U.S. 262, 311 (1932) (Brandeis, J., dissenting). 
Supreme Court often invokes this principle when declining to create a single binding federal rule for the entire country. ${ }^{95}$ But states may also have experience with a constitutional problem before it ever reaches the Supreme Court. And if the Court is going to respect the role of states as laboratories, then it would seem that whenever the Court confronts a federal constitutional problem with a state analogue, it might usefully learn from the experience of the state courts that got there first. After all, if the Court defers to states' laboratories while they work on a constitutional problem, shouldn't the Court take into account whatever answer they reach?

The use of the exclusionary rule, which is discussed in more detail below, ${ }^{96}$ provides an interesting and illustrative example. After the Supreme Court introduced the exclusionary rule in Weeks $v$. United States, ${ }^{97}$ many state courts followed suit under their own constitutional guarantees. Most influential of these was the California Supreme Court, which concluded that no other rule sufficed to deter unconstitutional searches and seizures. ${ }^{98}$ When, in Mapp v. Ohio, ${ }^{99}$ the Supreme Court incorporated the Fourth Amendment's exclusionary rule against the states, it did so based largely on California's experience. ${ }^{100}$ The Court followed the California Supreme Court's conclusion not necessarily out of respect for state sovereignty, but because the state had hands-on experience with a specific problem and had, in its role as a laboratory, settled on a solution. That kind of pragmatic borrowing is different in kind from borrowing based on respect for federalism as a political value. It is also different from using the states as some kind of barometer for "moral" or values-based inquiries, such as the Court arguably does in the due process and Eighth Amendment contexts.

In other words, state courts need not be independent laboratories. They can be part of the same general research institution as the Supreme Court. ${ }^{101}$ And respect for their work need not always lead the Supreme

95. See, e.g., Oregon v. Ice, 129 S. Ct. 711, 718-19 (2009); Arizona v. Evans, 514 U.S. 1, 8 (1995); Cruzan v. Dir., Mo. Dep’t of Health, 497 U.S. 261, 292 (1990) (O’Connor, J., concurring); Chandler v. Florida, 449 U.S. 560, 579-80, 582 (1981); Reeves, Inc. v. Stake, 447 U.S. 429, 441,446 (1980); San Antonio Indep. Sch. Dist. v. Rodriguez, 411 U.S. 1, 50 (1973); Johnson v. Louisiana, 406 U.S. 356, 376 (1972) (Powell, J., concurring).

96. See infra Part IV.B.1.

97. Weeks v. United States, 232 U.S. 383, 391-93 (1914).

98. People v. Cahan, 282 P.2d 905, 912-13 (Cal. 1955).

99. $\quad$ Mapp v. Ohio, 367 U.S. 643 (1961).

100. Id. at $651-52$.

101. See Kahn, supra note 75, at 1148 (explaining that state courts should be viewed as having "the authority to put into place, within [each] community, [their] unique interpretation [of a] common 
Court to avoid deciding issues; it can also be a factor in shaping the Court's own federal constitutional jurisprudence. ${ }^{102}$

\section{b. The Political Values of Federalism}

There is another federalism-related reason why state constitutional doctrine can be useful in resolving constitutional disputes: dividing power between the federal and state governments prevents either of them from overreaching, and can thereby help protect individual liberty. ${ }^{103}$

Many theories of federalism emphasize the important role of the states' political branches in preserving the federalist structure. The "political safeguards" theory of federalism, for example, focuses on the degree to which states can protect their own interests and sovereignty through political means. ${ }^{104}$ This view of federalism has, in turn, influenced the Court's constitutional jurisprudence, perhaps most notably in Garcia v. San Antonio Metropolitan Transit Authority, ${ }^{105}$ in which the Court held that the Tenth Amendment need not serve as an independent check on congressional power, since the states can protect themselves through the political process.

One may be left wondering, however, about the "judicial safeguards" of federalism. If the sharing of decisionmaking authority protects states and encourages better decisions in the political branches, it would seem that the same principle should apply to judicial decisionmaking. The state and federal judicial branches, after all, are every bit as intertwined as the state and federal legislatures, and far more so than state and federal executives. If the essence of federalism is that state actors must be given due respect within these spheres, then the suggestion that federal courts should consider borrowing state constitutional doctrine seems, if anything, too modest.

object").

102. Howard, supra note 45, at 879 (concluding, after reviewing state constitutional law regarding economic regulation, criminal procedure, religion, education, environment, and "autonomy and lifestyles," that "[t]he picture ... goes far in giving empirical vindication to the textbook portrait of the states in the Federal Union as vehicles for experimentation, with their achievements and their mistakes available for others to study").

103. THE FEDERALIST No. 51, at 258 (James Madison) (Lawrence Goldman ed., 2008) ("In the compound republic of America, the power surrendered by the people is first divided between two distinct [state and federal] governments, and then the portion allotted to each subdivided among distinct and separate departments. Hence a double security arises to the rights of the people. The different governments will control each other, at the same time that each will be controlled by itself.”).

104. See, e.g., Jesse H. ChOPER, Judicial Review AND the NATIONAL Political Process 17690 (1980); Herbert Wechsler, The Political Safeguards of Federalism: The Role of the States in the Composition and Selection of the National Government, 54 CoLUM. L. REV. 543, 558 (1954).

105. Garcia v. San Antonio Metro. Transit Auth., 469 U.S. 528, 551-54 (1985). 
This is not to suggest that current federal doctrine totally neglects state courts and state constitutions. But rather than encourage federal courts to engage directly with state constitutional law, present doctrine tends to adopt a much more categorical approach, requiring federal courts in certain situations to respect state law by avoiding it. Abstention principles do this by requiring federal courts to avoid hearing state court cases or state law claims. ${ }^{106}$ Perhaps the most easily recognizable of these is the independent and adequate state grounds rule, pursuant to which federal courts will decline to reverse the decision of a state court, even if it is based on an incorrect interpretation of federal law, so long as there are sufficient reasons for the decision that are grounded in state law. ${ }^{107}$

This line-drawing reflects a "dualist" vision of federalism. Under that view, states and the federal government are sovereign and independent in their own spheres, and the primary function of federalism jurisprudence is to maintain the boundary between them. ${ }^{108}$ As effectuated in the "federalism revolution" associated with the Rehnquist Court, this often meant limiting federal power and protecting the power of states. ${ }^{109}$ Jurisdictional rules that discourage state and federal courts from jointly addressing common constitutional issues make sense under this dualist vision because they preserve separate roles for state and federal courts. Such rules keep them from stepping on each other's toes by preventing them from dancing at all.

But many have begun to question whether the dualist vision is accurate as a descriptive matter or desirable as a normative one. Robert Schapiro, for example, explores what he calls "polyphonic federalism"110_

106. See, e.g., Colo. River Water Conservation Dist. v. United States, 424 U.S. 800, 817-21 (1976) (allowing abstention in cases of parallel litigation); Younger v. Harris, 401 U.S. 37, 52-54 (1971) (requiring, with limited exceptions, federal courts to abstain from hearing civil rights tort claims arising from criminal prosecution until the plaintiff/defendant is convicted); Burford v. Sun Oil Co., 319 U.S. 315, 333-34 (1943) (allowing federal abstention when state courts have greater expertise in the matter); R.R. Comm'n v. Pullman Co., 312 U.S. 496, 499-502 (1941) (holding that in most cases federal courts should not adjudicate the constitutionality of a state law until state courts have had a reasonable opportunity to do so).

107. See, e.g., Fox Film Corp. v. Muller, 296 U.S. 207, 210 (1935) (describing this as a "settled rule").

108. Younger, 401 U.S. at 44 (describing the idea of "Our Federalism" as "the belief that the National Government will fare best if the States and their institutions are left free to perform their separate functions in their separate ways").

109. See, e.g., Erwin Chemerinsky, The Federalism Revolution, 31 N.M. L. REV. 7, 7-8 (2001) (describing the Rehnquist Court's “federalism revolution”); Ernest A. Young, The Rehnquist Court's Two Federalisms, 83 Tex. L. Rev. 1, 2 (2004) (describing the same development as a "Federalist Revival").

110. Robert A. Schapiro, Polyphonic Federalism: State Constitutions in the Federal Courts, 87 
a federalism that "achieves its goals not through the separation of state and national power, but through their interaction." 111 That approach to federalism, it turns out, may well be a truer description of current practice and also a more attractive aspiration. Rather than seeing state and federal governments as fully independent entities, such theories cast them, in Gardner's words, as parts of an "interlocking plan of federalism devised collectively by the people of the nation and maintained by them as part of a comprehensive plan designed to serve the overriding national purpose of protecting the liberty of all Americans."112

If respecting federalism means more than simply drawing lines between state and federal court judgments, then abstention-type rules that quarantine the courts are not ideal. What is needed instead is an approach under which state and federal courts are not hermetically sealed off from each other, but rather partners in a shared enterprise of articulating constitutional values. Federal utilization of state constitutional law has the potential to do just that. Rather than simply insulating state court decisions from federal review, it would encourage federal courts to give increased consideration to state constitutional law, even in federal cases. Although this would require a more nuanced approach than the current rules of abstention, it would not be contrary to their general purposes. That is, if federalism is an adequate justification for requiring federal courts to avoid disturbing state court judgments, it would seem to follow that federalism principles might similarly require federal courts to be attuned to general state court doctrine even in cases governed by federal law. State courts, in other words, should be able to have a more generalized but less rigid impact on federal constitutional law-not just displacing it in those areas in which federal courts defer to state adjudication, but systematically influencing it whenever state and federal courts face similar constitutional questions.

State courts appear to be holding up their end of this arrangement (perhaps with too much enthusiasm) by borrowing heavily from federal doctrine. Federal courts, on the other hand, generally are not. And if the vision of federalism as a shared constitutional enterprise is to be effectuated in doctrine, federal courts should take better account of their cousins.

CALIF. L. REV. 1409, 1411 (1999) (defending “a robust role for federal courts in interpreting state constitutions").

111. Robert A. Schapiro, Toward a Theory of Interactive Federalism, 91 IowA L. REV. 243, 316 (2005).

112. Gardner, supra note 40, at 1005. 


\section{An “Objective” Measure of Current Constitutional Values}

The relationship between contemporary, popular constitutional values and constitutional doctrine has long bedeviled Justices and scholars. Some argue that the former should be irrelevant to the latter, ${ }^{113}$ others that the two are intertwined, ${ }^{114}$ and others that the latter is (and should be) meaningfully influenced by the former. ${ }^{115}$

Assuming for the moment that the search for contemporary constitutional values is a worthy enterprise, at least in some cases, it nonetheless faces evidentiary obstacles. Article V of the Constitution provides one way for the people to make their constitutional views heard, but its requirements are so rigid and cumbersome that formal amendments are, at best, an extremely rough barometer for current constitutional values. ${ }^{116}$ How, then, is one to know what the people think about a constitutional issue? The Court has no power to "certify" a question to the American people, and it seems unsatisfactory-base, even-to rely on polling data. Statutory enactments are a better measure, perhaps, since they arguably provide a more "objective" indicator of the current will of the people, as effectuated by their elected officials. And indeed the Court has often relied on state legislative enactments when charting the bounds of its due process, Fourth Amendment, and Eighth Amendment jurisprudence. ${ }^{117}$ But even assuming that state legislatures' views can be tallied (an assumption the Court frequently makes ${ }^{118}$ ), if the Constitution is interpreted according to state legislative enactments, how can it prevent state legislatures from overreaching?

What is needed is some middle ground between the rigidity of the Article V process and the fuzziness of public polling. State constitutional law can help provide that middle ground. As the formal constitutive

113. Cf. 1 Joseph StORy, COMMENTARIES ON THE CONSTITUTION OF THE UNITED STATES § 426, at 326 (5th ed. 1891) (" $[T]$ he policy of one age may ill suit the wishes or the policy of another. The Constitution is not to be subject to such fluctuations. It is to have a fixed, uniform, permanent construction. It should be, so far at least as human infirmity will allow, not dependent upon the passions or parties of particular times, but the same yesterday, to-day, and forever.").

114. See generally BARRY Friedman, THE Will of the People (2009) (arguing that the Supreme Court is deeply engaged with, and rarely strays far from, public opinion).

115. Cf. Robert Post \& Reva Siegel, Popular Constitutionalism, Departmentalism, and Judicial Supremacy, 92 CALIF. L. REv. 1027, 1029 (2004) ("The question we pursue, therefore, is how the nation can strike a viable balance between the rule of law and the people's authority to speak to issues of constitutional meaning.").

116. See U.S. CONST. art. V (describing the amendment process).

117. See Hills, supra note 8, at 17-18.

118. Id. 
documents of the sovereign states, state constitutions are not as hard to amend as the federal Constitution, ${ }^{119}$ but are usually harder to alter than a statute is to pass. ${ }^{120}$ Similarly, the decisions of elected state judges-who, unlike the Justices, have a formal incentive to follow "th' iliction returns"121_are likely to be at least a rough approximation of the constitutional values of their states' citizens, since state supreme court justices can be voted out of office if they deviate too far from those values.

State constitutions may be a particularly good measure of public values when they are amended or reinterpreted in response to a Supreme Court decision. This is not an uncommon occurrence, and at times the Supreme Court has taken note of it. After the Court held in Bowers v. Hardwick that a Georgia law prohibiting sodomy was not unconstitutional under the federal Due Process Clause, ${ }^{122}$ the Georgia courts found that the law violated Georgia's analogous constitutional provision. ${ }^{123}$ Other states followed suit, some by amending their constitutions and some through court decisions. ${ }^{124}$ Of course, the matter could have come to rest right there, since states are free to protect more or different rights than the federal Constitution. But when the Supreme Court reversed Bowers fewer than twenty years later in Lawrence v. Texas, ${ }^{125}$ it specifically relied on the states' constitutional response as a barometer of whether the right at issue was "fundamental." "26 Thus, where the constitutional inquiry itself demands some measure of current values—as modern due process doctrine arguably does - state constitutional law may be a useful evidentiary tool. State courts can therefore partner with federal courts in the shared project

119. Cf. Adam Winkler, Heller’s Catch-22, 56 UCLA L. REV. 1551, 1574 (2009) (“Today, fortytwo of the fifty state constitutions provide for the individual right to keep and bear arms unrelated to militia service-by far the best expression of the constitutional commitments of We the People." (footnote omitted)).

120. See infra Part III.B.2.

121. Ernest A. Young \& Erin C. Blondel, Does the Supreme Court Follow the Economic Returns? A Response to a Macrotheory of the Court, 58 DUKE L.J. 1759, 1759 (2009) (quoting FINLEY PETER DUNNE, MR. DOOLEY's OPINIONS 26 (1901)).

122. Bowers v. Hardwick, 478 U.S. 186, 189-96 (1986).

123. Powell v. State, 510 S.E.2d 18, 26 (Ga. 1998).

124. See, e.g., Jegley v. Picado, 80 S.W.3d 332, 349-54 (Ark. 2002); Commonwealth v. Wasson, 842 S.W.2d 487, 492 (Ky. 1992); Gay \& Lesbian Advocates \& Defenders v. Att’y Gen., 763 N.E.2d 38, 40-41 (Mass. 2002); Williams v. State, 722 A.2d 886 (Md. 1999) (holding at the trial court level that sodomy statute did not apply to consensual, noncommercial, private sexual behavior, and the decision was not appealed by the State); Gryczan v. State, 942 P.2d 112, 123-26 (Mont. 1997); Campbell v. Sundquist, 926 S.W.2d 250, 260-66 (Tenn. Ct. App. 1996); State v. Morales, 826 S.W.2d 201, 204-05 (Tex. App. 1992).

125. Lawrence v. Texas, 539 U.S. 558 (2003).

126. Id. at 576 . 
of identifying and expounding constitutional values. ${ }^{127}$

Even those who are skeptical of relying on contemporary constitutional values would surely agree that state constitutional amendments can be a better gauge of those values than, say, Gallup polls. ${ }^{128}$ Even so, one might reasonably question how much weight state constitutional doctrine should receive. It has been reported that a majority of Americans are not even aware that their states have constitutions, much less what they contain. ${ }^{129}$ If that is so, then it can hardly be said that those constitutions reflect their values in any meaningful way. And yet it would also be too much to conclude that citizens are indifferent to state constitutional law or state courts. For evidence that people are perfectly willing and able to engage with state constitutional law when it touches on an issue that matters to them, one need look no further than the public outcry in response to the Massachusetts Supreme Judicial Court's decision validating same-sex marriage, ${ }^{130}$ the purge of the California Supreme Court after the justices on that court were labeled "soft on crime" in the $1980 \mathrm{~s},{ }^{131}$ or the Iowa elections in which three of the justices who extended constitutional protection to gay marriage in 2009 were voted out of office. $^{132}$ To the degree that citizens actively engage with state constitutional law issues, state constitutional law should serve as a relatively accurate barometer of their current constitutional values.

\section{Comparativism}

Finally, the simplest argument for federal borrowing of state constitutional law may be that it is a near-ideal form of comparative constitutionalism.

127. See Lawrence Gene Sager, Foreword, State Courts and the Strategic Space Between the Norms and Rules of Constitutional Law, 63 TEX. L. REv. 959, 973 (1985) (“The idea that constitutional judges throughout the United States are engaged in a common enterprise, are colleagues in the effort to shape and explicate a common tradition of political morality, is an attractive one.”).

128. Cf. Atkins v. Virginia, 536 U.S. 304, 347 (2002) (Scalia, J., dissenting) ("[T]he views of professional and religious organizations and the results of opinion polls are irrelevant.”).

129. Gardner, supra note 33, at 829 (citation omitted).

130. See Pam Belluck \& Katie Zezima, Hearts Beat Fast to Opening Strains of the Gay-Wedding March, N.Y. Times, May 16, 2004, § 1, at 26; Alan Cooperman, Massachusetts Clergy Are Divided on Eve of Historic Same-Sex Unions, WASH. Post, May 16, 2004, at A01; John McElhenny, Church Groups Rally on Gay Marriage, Boston GLOBE, Mar. 8, 2004, at B3.

131. See generally John T. Wold \& John H. Culver, The Defeat of the California Justices: The Campaign, the Electorate, and the Issue of Judicial Accountability, 70 JUDICATURE 348 (1987) (describing the debate and surrounding events leading up to the election).

132. See Krissah Thompson, Gay Marriage Fight Targeted Iowa Judges, Politicizing Rulings on Issue, WASH. POST, Nov. 3, 2010. 
Comparativism has long been a part of the Supreme Court's interpretive toolkit, perhaps increasingly so in recent years. For example, the Court has often relied on international and foreign law in Eighth Amendment cases, beginning with its seminal decision in Trop v. Dulles ${ }^{133}$ and continuing through its more recent decisions in Atkins v. Virginia ${ }^{134}$ and Roper v. Simmons. ${ }^{135}$ International comparativism has also become a part of the Court's due process jurisprudence. In Lawrence $v$. Texas, ${ }^{136}$ for example, the majority noted that the European Court of Human Rights had recently struck down the United Kingdom's sodomy ban in Dudgeon $v$. United Kingdom. ${ }^{137}$ The Supreme Court observed that "[o]ther nations, too, have taken action consistent with an affirmation of the protected right of homosexual adults to engage in intimate, consensual conduct.”138 This kind of international comparativism is thought to be especially useful when the comparator countries have constitutional systems similar to ours. ${ }^{139}$ As Justice Breyer has noted, the "Court has long considered as relevant and informative the way in which foreign courts have applied standards roughly comparable to our own constitutional standards in roughly comparable circumstances." 140 And even when it comes to countries whose traditions differ from ours, foreign constitutional precedents may be relevant to federal constitutional interpretation "simply because of the enormous value in any discipline of trying to learn from the similar experience of others." 141

Comparativism is also prevalent among the states themselves. State courts often cite one another's decisions ${ }^{142}$ and borrow one another's

133. Trop v. Dulles, 356 U.S. 86, 102-03 (1958) (plurality opinion).

134. Atkins v. Virginia, 536 U.S. 304, 316 n.21 (2002).

135. Roper v. Simmons, 543 U.S. 551, 575-78 (2005).

136. Lawrence v. Texas, 539 U.S. 558, 573 (2003).

137. Dudgeon v. United Kingdom, 45 Eur. Ct. H.R. (ser. A) at 25 (1981).

138. Lawrence, 539 U.S. at 576. See also id. at 573.

139. See, e.g., William Rehnquist, Constitutional Courts-Comparative Remarks, in 14 GERMANY and Its Basic LaW: Past, PRESENT ANd Future-A German-American Symposium 411, 412 (Paul Kirchhof \& Donald P. Kommers eds., 1993) (“[N]ow that constitutional law is solidly grounded in so many countries, it is time that the United States courts begin looking to the decisions of other constitutional courts to aid in their own deliberative process.”).

140. Knight v. Florida, 528 U.S. 990, 997 (1999) (Breyer, J., dissenting from denial of certiorari).

141. Stephen Breyer, Keynote Address, 97 Am. Soc’y InT’L L. Proc. 265, 266 (2003). See also Sandra Day O’Connor, Keynote Address, 96 AM. SoC’Y INT’L L. Proc. 348, 350 (2002) (“[T]here is much to learn from other distinguished jurists who have given thought to the same difficult issues that we face here.”).

142. See also Gregory A. Caldeira, The Transmission of Legal Precedent: A Study of State Supreme Courts, 79 AM. POL. SCI. REv. 178, 179-80 (1985) (surveying scholarly studies on the interactions among courts of different states); Lawrence M. Friedman et al., State Supreme Courts: A Century of Style and Citation, 33 STAN. L. REV. 773, 796-97 (1981) (summarizing data regarding state 
doctrine, ${ }^{143}$ even in constitutional cases. ${ }^{144}$ They do so despite the fact that they are no more bound by one another's precedents when interpreting their own law than the Supreme Court is when interpreting federal law. Thus, the federal courts borrow from international sources, state courts borrow freely from one another, and-as noted above-state courts borrow from federal courts. What is largely missing, however, is intranational borrowing by federal courts. If international law can be a valid comparator, then why not also the law of those sovereign states whose constitutional tradition is historically, culturally, and formally enmeshed with the nation's? ${ }^{145}$

Of course, comparativism is controversial. Those opposed to its international variant—including, perhaps most vocally, Justice Scalia ${ }^{146}$ complain that it amounts to substituting other countries' views for our own, and imports principles from countries whose constitutional traditions (assuming that they exist) are very different from ours. But these arguments against comparativism are far weaker when American state constitutions are the subject of the comparison, because "the differences between the relevant state constitutions and the federal Constitution are much smaller than the differences involved in the transnational comparisons that are a staple of comparative constitutional law." ${ }^{147}$ As described in more detail in Part II, state constitutions—and the state courts' gloss on them—are often

court citations). See generally Patrick Baude, Interstate Dialogue in State Constitutional Law, 28 RUTGERS L.J. 835 (1997) (examining state court references to constitutions of other states); Bradley C. Canon \& Lawrence Baum, Patterns of Adoption of Tort Law Innovations: An Application of Diffusion Theory to Judicial Doctrines, 75 Am. PoL. SCI. REV. 975 (1981) (using statistical methods to study the diffusion of state judicial doctrines).

143. See Shirley S. Abrahamson \& Michael J. Fischer, All the World's a Courtroom: Judging in the New Millennium, 26 HofSTRA L. REV. 273, 285 (1997) (noting that state supreme court justices have become "seasoned comparatists").

144. Margaret H. Marshall, "Wise Parents Do Not Hesitate to Learn from Their Children": Interpreting State Constitutions in an Age of Global Jurisprudence, 79 N.Y.U. L. REV. 1633, 1641-42 (2004) ("As a state court judge, I have frequent occasion to look to the constitutional law of fifty other American jurisdictions, even though other states' interpretations of their constitutions have no precedential weight for Massachusetts.”).

145. See Martha F. Davis, The Spirit of Our Times: State Constitutions and International Human Rights, 30 N.Y.U. REV. L. \& Soc. CHANGE 359, 374 (2006) (comparing federal citation of international materials and state court citation of other states' decisions); Note, State Law as "Other Law": Our Fifty Sovereigns in the Federal Constitutional Canon, 120 HARV. L. REV. 1670, 1672 (2007) (questioning "the disparate attitudes toward the Court's use of state and foreign law").

146. See, e.g., Roper v. Simmons, 543 U.S. 551, 624 (2005) (Scalia, J., dissenting) (“[T]he basic premise of the Court's argument-that American law should conform to the laws of the rest of the world—ought to be rejected out of hand.”); Antonin Scalia, Commentary, 40 ST. LOUIS U. L.J. 1119, 1119 (1996) (arguing against reliance on "international norms”).

147. Adrian Vermeule, The Judicial Power in the State (and Federal) Courts, 2000 SuP. CT. Rev. $357,359$. 
substantially identical to the federal Constitution. Indeed, "The development of individual rights under [state] Bills of Rights has been a cooperative, common law-like effort by federal and state courts." 148 If that development is to be truly cooperative, then federal courts should do more to take into account interpretations of the state courts with which they are supposedly cooperating.

\section{B. ARgUMENTS AgAinst}

The purpose of this Article is not to present a unified theory of constitutional interpretation, but to consider carefully whether one particular interpretive tool is worthwhile, and under what circumstances. This section therefore aims to evaluate the arguments against increased federal reliance on state constitutional law.

\section{Conflicts with Originalism, Textualism, and Positivism}

It would appear that originalists and textualists are unlikely to have much interest in using contemporary state constitutional doctrine to illuminate the federal document. ${ }^{149}$ Strict originalists focus on the intent, understandings, and practices in place when the federal Constitution was written and ratified. ${ }^{150}$ The modern constitutional practices of statesparticularly those states that did not even exist in the late 1700s-are therefore presumably irrelevant except perhaps to the degree that they elucidate or rely on Founding-era materials. Textualists, in turn, focus on specific words in the federal Constitution, and often do so through an originalist lens by looking for Founding-era sources ${ }^{151}$ or contextual clues within the federal Constitution itself. ${ }^{152}$ Again, contemporary state

\footnotetext{
148. Force, supra note 42, at 130.

149. State Law as "Other Law," supra note 145, at 1681 ("Under originalism, both contemporary state and foreign sources are likely irrelevant to constitutional interpretation.”).

150. Robert H. Bork, THE TEMPting of America 144 (1990) ("All that counts is how the words used in the Constitution would have been understood at the time. The original understanding is thus manifested in the words used and in secondary materials, such as debates at the conventions, public discussion, newspaper articles, dictionaries in use at the time, and the like."); Antonin Scalia, Originalism: The Lesser Evil, 57 U. CIN. L. REV. 849, 851-52 (1989) (explaining that the “'originalist' approach to constitutional interpretation" includes "examining various evidence, including not only, of course, the text of the Constitution and its overall structure, but also the contemporaneous understanding..., the background understanding... under the English constitution, and...the various state constitutions in existence when the federal Constitution was adopted").

151. See, e.g., William Michael Treanor, Against Textualism, 103 Nw. U. L. REV. 983, 984 (2009) (citing textualist use of Founding-era materials).

152. See Akhil Reed Amar, Intratextualism, 112 HARV. L. REV. 747, 788-801 (1999) (describing the theory of "intratextualism," under which the meaning of constitutional text is established in part by
} 
constitutional law seems unlikely to offer much useful guidance.

More generally, objections to constitutional borrowing of any kind may be grounded in a certain view of legal positivism, a concept that has made frequent appearances in debates about state constitutionalism. Gardner explains that positivism "requires courts to approach a constitution as an authoritative expression of the will of the people who made it, and to interpret the constitution strictly in accordance with that popular will as it is expressed in the document." 153 In other words, one cannot compare state constitutional apples to the federal orange, because they were produced by different sets of "the people." Invoking this principle, some scholars and judges argue that state constitutions are unique and must be interpreted in light of their specific texts, original intents and original understandings, ${ }^{154}$ or in line with the character of the states themselves, ${ }^{155}$ rather than in accordance with federal constitutional principles. One could easily turn the argument around to say that federal courts should not borrow state law for precisely the same reasons.

uses of other, similar language elsewhere in the document).

153. James A. Gardner, Whose Constitution Is It? Why Federalism and Constitutional Positivism Don't Mix, 46 WM. \& MARY L. REV. 1245, 1245 (2005).

154. See Gardner, supra note 153, at 1246 ("Sometimes a jurisprudence of state constitutional positivism is justified on the ground that, because state constitutions are so easily and frequently amended, it is often possible to discern 'the framers' true intent' in a way that is sometimes impossible to accomplish when interpreting the U.S. Constitution due to its age.” (footnote omitted)); Howard, supra note 45, at 936 ("A state's history and traditions should be considered. Early events often throw considerable light on constitutional interpretation in states tending to strict separation of church and state.”); Thomas Morawetz, Deviation and Autonomy: The Jurisprudence of Interpretation in State Constitutional Law, 26 ConN. L. REv. 635, 640 (1994) (“[S]tate judges sometimes justify deviant interpretations of rights by arguing that the drafters of relevant state provisions had different intentions from those of the federal framers.”); G. Alan Tarr, State Constitutional Interpretation, 8 TEX. REV. L. \& PoL. 357, 357 (2004) ("The interpretation of state constitutions, like the interpretation of the federal Constitution, should be rooted in the text and original understanding of the document.").

155. See Shirley S. Abrahamson, Reincarnation of State Courts, 36 Sw. L.J. 951, 965 (1982) ("I look at the peculiarities of my state-its land, its industry, its people, its history.”); Judith S. Kaye, Dual Constitutionalism in Practice and Principle, 61 ST. JoHN's L. REV. 399, 423 (1987) ("It should be immediately apparent that the Constitution established by New York ... reflects its own values, which may or may not be identical to those held elsewhere."); Ronald L. Nelson, Welcome to the "Last Frontier," Professor Gardner: Alaska's Independent Approach to State Constitutional Interpretation, 12 Alaska L. ReV. 1, 5-8 (1995) (outlining Alaska's unique history and traditions); Peter R. Teachout, Against the Stream: An Introduction to the Vermont Law Review Symposium on the Revolution in State Constitutional Law, 13 VT. L. REV. 13, 35 (1988) ("The keystone is the development in each state of a jurisprudence that is faithful to that state's particular constitutional traditions.”); Don S. Willner, Constitutional Interpretation in a Pioneer and Populist State, 17 WillametTe L. Rev. 757, 777-78 (1981) (outlining the distinctive qualities of Oregon that should influence its jurisprudence). See generally R. Lawrence Hachey, Jacksonian Democracy and the Wisconsin Constitution, 62 MARQ. L. REV. 485 (1979) (describing the origins of the Wisconsin Constitution). 
Nevertheless, there are reasons to think that the originalist, textualist, and positivist objections are not necessarily devastating. Even the most committed originalists and textualists use Framing-era state constitutions to interpret the federal document. ${ }^{156}$ Justice Scalia's majority opinion in Heller - which has been called the leading originalist opinion the Court has ever issued ${ }^{157}$ — does so, ${ }^{158}$ as does Justice Alito's originalist opinion for the plurality in McDonald. ${ }^{159}$ This makes perfect sense, of course, given that the federal Constitution was modeled on state constitutions, rather than the other way around. ${ }^{160}$ Moreover, just as originalists often look to scholarship for illumination of original intents or understandings, so too might they turn to state court decisions that are themselves originalist. ${ }^{161}$ The originalist and textualist objections to reliance on state law therefore may not be quite as unqualified as they first appear.

The positivist objection, too, can be partially answered. As an argument against federal borrowing of state constitutional law, the positivist objection fails for the simple reason that the federal system is not independent of state constitutional law. That is, the federal Constitutionboth in its explicit terms and in the constitutional culture it creates-is deeply intertwined with state constitutions and state constitutionalism. The will of "the people" who made the federal Constitution, as expressed in that document, is emphatically one that respects states and state identity. Indeed, the federal Constitution and all of its amendments were ratified by the states, not directly by "the people." Because state constitutions are deeply intertwined with the federal Constitution - they inspired it and are modeled after it - comparativism cannot be ruled out on the basis of the

156. Scalia, supra note 150, at 852. See also Powell, supra note 50, at 283 ("[B]oth legal history and constitutional jurisprudence would benefit from enhanced attention to those traditions of argument and interpretation that center on the fundamental law of the several states rather than on the federal Constitution.”). See generally LUTZ, supra note 14 (arguing that understanding the U.S. Constitution requires understanding state constitutions).

157. District of Columbia v. Heller, 554 U.S. 570 (2008). See also, e.g., Randy E. Barnett, News Flash: The Constitution Means What It Says, WALL ST. J., June 27, 2008, at A13 ('Justice Scalia's opinion is the finest example of what is now called 'original public meaning' jurisprudence ever adopted by the Supreme Court.").

158. See Heller, 554 U.S. at 577 (interpreting the Second Amendment's first clause as "prefatory" in light of the fact that "other legal documents of the founding era, particularly individual-rights provisions of state constitutions, commonly included a prefatory statement of purpose"); id. at 640-42 (Stevens, J., dissenting).

159. McDonald v. City of Chicago, 130 S. Ct. 3020, 3037-38 (2010) (plurality opinion).

160. See LUTZ, supra note 14, at 97.

161. See, e.g., State v. Sieyes, 225 P.3d 995, 1005 (Wash. 2010) ("We follow Heller ... [and] look to the Second Amendment's original meaning, the traditional understanding of the right, and the burden imposed on children by upholding the statute.”). 
documents' supposed independence from each other.

\section{The "Political" Nature of State Constitutional Law}

Holding aside for a moment the differences in substantive rights guaranteed by state constitutions and the federal Constitution-an issue described in more detail in the following subsection-there are also important differences in their political responsiveness. The federal Constitution, of course, is largely impervious to political concerns. Amending it requires ratification by three quarters of the states, which is, of course, an extremely high bar. ${ }^{162}$ And although Supreme Court Justices may in fact tend to stay within the political mainstream, ${ }^{163}$ Article III formally insulates them from politics by guaranteeing life tenure and nondiminution of salary. ${ }^{164}$ This entrenchment leads to the most famous constitutional "difficulty" of all—the countermajoritarian one-but it is also essential to the Constitution's role in protecting unpopular groups and rights.

State constitutional law, by contrast, is not nearly so far removed from politics, and therefore one might reasonably question whether it should serve as a model for the federal Constitution. This overarching concern can be divided into two arguments: state constitutions are too easily amended, and state court judges are too politically responsive.

\section{a. State Constitutions Are Too Easily Amended}

The biggest difference between state constitutions and their federal counterpart might lie not in the rights they protect, but in the relative ease with which the former can be amended, altered, or replaced. This malleability, in turn, contributes to further substantive differences between the documents.

In contrast to the rigid requirements of Article V, state constitutions can be amended through a wide array of methods, including popular initiative, ${ }^{165}$ convention, constitutional commission, ${ }^{166}$ and legislative

162. U.S. CONST. art. V.

163. See generally FRIEDMAN, supra note 114 (describing tensions that result in balance between majoritarian values and judicial review).

164. U.S. CONST. art. III, § 1.

165. See generally DAVID D. SCHMidT, CITIZEN LAWMAKERS: THE BALlOT INITIATIVE REVOLUTION (1989) (describing the political trends and events that led to a much wider use of voterinitiated propositions nationwide beginning in the 1970s).

166. Robert F. Williams, Are State Constitutional Conventions Things of the Past? The Increasing Role of the Constitutional Commission in State Constitutional Change, 1 HOFSTRA L. \& POL'Y SYMP. 1, 22-26 (1996) (analyzing the rise in the use of constitutional commissions, and concluding that they 
proposal. ${ }^{167}$ Those mechanisms have been frequently employed to amend state constitutions and even to replace them entirely. By Alan Tarr's count, "Only nineteen states retain their original constitutions, and most states have had three or more." 168 Although a dozen state constitutions predated the federal Constitution, only three states-Massachusetts, Vermont, and New Hampshire-still have the constitutions they adopted in the eighteenth century. ${ }^{169}$ Fifteen state constitutions were adopted in the final twenty-five years of the 1800s, and eighteen more were adopted after $1900 .{ }^{170}$ As of thirty years ago, the states had created a total of at least 145 constitutions. ${ }^{171}$

Even when state constitutions are not replaced entirely, they are amended with dizzying frequency. According to one estimate, there were 4700 state constitutional amendments between 1776 and $1980 .{ }^{172}$ It should be noted, though, that a handful of states bear disproportionate responsibility for those numbers. By 1982, the Alabama Constitution had been amended more than 500 times, the California and South Carolina Constitutions each more than 400 times, and the Texas Constitution more than 200 times. $^{173}$ If anything, the pace has accelerated since then. By 2006, Alabama was up to 772 amendments, California to 514, South Carolina to 485 , and Texas to $432 .{ }^{174}$ But they are by no means the only states to amend their constitutions frequently; most have averaged more than one amendment per year of their existence. ${ }^{175}$

To the degree that state constitutions can be altered on a whim, they

"may also provide a fourth means to propose constitutional change directly to the people, in addition to the convention, the legislative route, or (where it exists) the initiative process").

167. See Teresa Stanton Collett, Judicial Independence and Accountability in an Age of Unconstitutional Constitutional Amendments, 41 LOY. U. CHI. L.J. 327, 334-35 (2010) (summarizing the four methods of state constitutional amendment). Variations exist. Delaware allows for amendments solely by the General Assembly, DEL. CONST. art. XVI, §1, and Florida allows for a constitution revision commission to meet every twenty years and propose amendments, FLA. CONST. art. XI, § 2.

168. Tarr, supra note 154, at 359 (citing TARR, supra note 40, at 23).

169. Gardner, supra note 33, at 811 (citing Albert L. Sturm, The Development of American State Constitutions, 12 PUBLIUs 57, 75-76 (1982)).

170. Id.

171. Sturm, supra note 170 , at 57.

172. James A. Henretta, Foreword, Rethinking the State Constitutional Tradition, 22 RUTGERS L.J. 819, 829 (1991) (citation omitted).

173. Gardner, supra note 33, at 820 (citing Sturm, supra note 169, at 75-76 tbl.3).

174. See Robert L. Maddex, State Constitutions of the United States, at xxxiii-xxxvii (2d ed. 2006).

175. Tarr, supra note 154, at 359 (citing TARR, supra note 40, at 24). See also Janice C. May, Amending State Constitutions 1996-97, 30 RUTGERS L.J. 1025, 1025 (1999) (noting that from 1996 to 1997 alone, forty-two states considered 233 amendments, approving 178 of them (citation omitted)). 
may not accurately reflect entrenched constitutional values. But this is the inevitable tradeoff between timelessness and timeliness. State constitutions tend toward the latter; the federal Constitution toward the former. Each has its advantages and disadvantages. For example, whenever federal constitutional interpretation requires consideration of contemporary values, the ease with which state constitutions can be amended may in fact make them a valuable and accurate barometer. ${ }^{176}$ Robert Williams notes that "proposed amendments to state constitutions sometimes provide a forum for resolving major societal conflicts." 177 Because they have been amended so often, state constitutions contain a "layering" of different generations' constitutional concerns. ${ }^{178}$ As A.E. Dick Howard explains, "State constitutions are a peculiarly useful mirror of fundamental values.”179

\section{b. State Judges Are Elected}

There is a second potential problem with the "political" nature of state constitutional law, one that springs not from the constitutions themselves but from the manner in which state judges are selected. Because many state judges are elected, and therefore politically responsive in ways that their federal counterparts are not, they may bend in the wind too much to serve as trustworthy and steady evaluators of constitutional rights.

The problems raised by judicial elections have been well covered elsewhere and need not be rehashed in any detail here. ${ }^{180}$ In general, however, it would seem that if state judges are attuned to the whims of the popular electorate, then they will tend to underprotect unpopular rights and unpopular groups. And while it may be true that most voters, most of the time, do not know or care who their state judges are, they are nonetheless capable of mobilizing whenever the courts stray too far from majority public opinion in defense of unpopular people or principles. Perhaps the most well-known example is the bitter and successful campaign against Chief Justice Rose Bird and her colleagues on the California Supreme Court after they struck down California's death penalty statute and were

176. Howard, supra note 45, at 938-39.

177. Robert F. Williams, State Constitutional Law Processes, 24 WM. \& MARY L. REV. 169, 176 (1983).

178. Robert F. Williams, State Constitutional LaW: Cases and Materials 19 (2d ed. 1993).

179. Howard, supra note 45, at 938-39.

180. See, e.g., David E. Pozen, The Irony of Judicial Elections, 108 CoLUM. L. REV. 265, 287-89 (2008). For a nuanced account of state courts' treatment of "backlash," see Neal Devins, How State Supreme Courts Take Consequences into Account: Toward a State-Centered Understanding of State Constitutionalism, 62 STAN. L. REV. 1629 (2010). 
generally accused of coddling criminals. ${ }^{181}$ Other examples are not hard to find. ${ }^{182}$ State judges trying to avoid a similar fate may feel pressured to adopt federal constitutional law as their own. ${ }^{183}$ As Justin Long notes, "The public, not knowing (or caring) much about state constitutions or state high courts, sees only a state court refusing to follow precedent from 'the highest court in the land,' and by that refusal, protecting a disfavored group's rights over the wishes of the electoral majority." 184

These political considerations raise concerns about federal borrowing of state constitutional law. Most importantly, they suggest that "reverse incorporating" state constitutional law-which for all the reasons listed above is likely to underprotect rights-would effectively weaken federal constitutional protections. ${ }^{185}$ One response to this concern might be to say that state constitutional underprotection should not be a problem because state constitutional protections cannot fall below the federal "floor." But that move, attractive as it may be, is not available. If state constitutional law is used to define the federal constitutional floor, then it is no answer to say that the federal floor will prevent underprotection by states.

There are other ways to minimize the problem, however. It is possible that the political accountability of state judges (and the amendability of state constitutions) might encourage them to read state constitutions more expansively, knowing that their rulings can always be "corrected" by a democratic majority. ${ }^{186}$ Moreover, for precisely the same reasons that the

\footnotetext{
181. See supra note 131 and accompanying text.

182. See, e.g., Friesen, supra note 81, at 34-36.

183. Cf. State v. Hempele, 576 A.2d 793, 815-16 (N.J. 1990) (O’Hern, J., dissenting) (objecting
} to the court's divergence from Supreme Court doctrine and arguing that "[t]o the extent possible, we ought not personalize constitutional doctrine. When we do otherwise, we vindicate the worst fears of the critics of judicial activism").

184. Long, supra note 83, at 65-66. See also Williams, In the Supreme Court's Shadow, supra note 4, at 368 ("[S]tate courts now face mounting criticism for reaching 'result-oriented' decisions. Without more of a justification, state courts may face criticism regardless of the persuasiveness of their state constitutional analysis.”); Robert F. Williams, State Courts Adopting Federal Constitutional Doctrines: Case-By-Case Adoptionism or Prospective Lockstepping?, 46 WM. \& MARY L. REV. 1499, 1525 (2005) [hereinafter Williams, State Courts] ("When two sets of interpreters reach the same outcome in a constitutional case, this increases confidence that the result is rooted in law rather than in will." (quoting TARR, supra note 40, at 175-76)).

185. Those who believe that federal constitutional rights are already too expansive are unlikely to be troubled by this, of course.

186. See, e.g., Commonwealth v. O’Neal, 339 N.E.2d 676, 694 (Mass. 1975) (Hennessey, J., concurring) ("[I]f the present will of the people of the Commonwealth is that capital punishment should be permitted in some or all cases of murder in the first degree, procedures for amendment of the State Constitution which are relatively speedy, but still require time for reasonable reflection, are available to accomplish that end.”); Schapiro, supra note 110, at 1453 (“[T] $]$ heir greater accountability might render state judges more willing to read state constitutional guarantees expansively.”); Robert S. Thompson, 
malleability of state constitutions makes them particularly good markers of current constitutional values, so too should the electability of state judges make them especially accurate expositors of those values. Their articulation of constitutional values may well lead to a "reinvigoration of the discursive ground of a democratic order committed to the rule of law," in part because state courts' "institutional position can be thought of as intermediate between that of federal judges and that of elected representatives."187

\section{The Impossibility or Unhelpfulness of Comparison}

A final group of objections centers on the basic idea that it is either unhelpful or impossible to compare state and federal constitutions.

\section{a. State Constitutions Are Too Different}

One argument against using state constitutional law to guide federal constitutional interpretation is that state constitutions simply have too little in common-either with the federal Constitution ${ }^{188}$ or with one another ${ }^{189}$ _for comparisons to be illuminating.

It is undoubtedly true that state constitutions differ from the federal Constitution in the rights they protect. As noted above, state constitutions generally protect at least the same rights as are listed in the federal Bill of Rights. But some employ different and more elaborate language in doing so. ${ }^{190}$ And in addition to those rights, state constitutions also typically guarantee other rights not mentioned in the federal document. ${ }^{191}$ For example, "every state constitution dwells at length on education, and most have something to say about conservation and the environment; the federal

Judicial Retention Elections and Judicial Method: A Retrospective on the California Retention Election of 1986, 61 S. CAL. L. REV. 2007, 2055 (1988) ("Subjecting state appellate judges to electoral accountability conceivably justifies these judges in erring more freely on the side of overprotection.").

187. Kahn, supra note 75, at 1155-56. See generally David E. Pozen, Judicial Elections as Popular Constitutionalism, 110 COLUM. L. REV. 2047 (2010) (arguing that election of state judges may serve as a mechanism of popular constitutionalism).

188. Rodriguez, supra note 87, at 272 ("[S]tate constitutions differ fundamentally from the federal constitution in their respective histories, their political theories, and the intra-state circumstances to which they respond, if imperfectly, as instruments of public governance.”).

189. Ellen A. Peters, State Constitutional Law: Federalism in the Common Law Tradition, 84 MICH. L. REV. 583, 586 (1986) ("State constitutions thus exhibit much greater diversity in origin and in agenda-some were intended, for example, to facilitate acceptance into the union-than we are accustomed to contemplate from a federal vantage point."(footnote omitted)).

190. See, e.g., Howard, supra note 45, at 910 ("Religion clauses in state constitutions take many forms. Some parallel the First Amendment. More commonly, they are both longer and more detailed than the First Amendment.”).

191. Gardner, supra note 40, at 1028-29. See also supra note 45 and accompanying text. 
Constitution mentions neither." ${ }^{292}$ Indeed, federal constitutional law all but disavows any government obligation to ensure or protect such rights.

In addition to the breadth of the rights they protect, state constitutions are almost statute-like in their length and attention to detail. One commonly invoked piece of evidence in this regard is the New York Constitution's direct regulation of the width of ski trails. ${ }^{193}$ The original, unamended federal Constitution, by contrast, consists of fewer than 5000 words, including signatures, and a vast amount of federal legislative authority derives from only seven of them ("To regulate Commerce ... among the several States"). ${ }^{194}$ Given their detail, it is unsurprising that, on average, state constitutions are four times longer than the federal Constitution. ${ }^{195}$ And even holding aside differences in particularities, federal and state constitutions are differently situated for the simple reason that state and federal governments are. The federal government, of course, can act only pursuant to its enumerated powers, while states have the police power and can act unless prohibited. The federal Constitution therefore grants power; state constitutions limit it. ${ }^{196}$

These are important differences and should not be minimized. And yet there are still areas of overlap. Although state constitutions may go much further than the federal Constitution in terms of the rights they enumerate and protect, they do tend to protect at least the same rights as the federal Constitution. That, after all, is precisely the reason why state courts are able to interpret their constitutions in "lockstep" with the federal Constitution. And even where state constitutions differ in substance or detail from their federal counterpart, a careful interpretive approach can take these differences into account. For example, the right to privacy exists in the federal system as an incident of substantive due process. Some states, however, have adopted specific constitutional provisions to protect the right, rather than relying on due process. ${ }^{197}$ Thus, a federal court looking to state constitutional doctrine to determine whether the right to privacy is

192. Howard, supra note 45, at 935.

193. Judith S. Kaye, A Midpoint Perspective on Directions in State Constitutional Law, 1 EMERGING IssuES ST. CONST. L. 17, 18-19 (1988) (discussing N.Y. CONST. art. XIV, § 1).

194. U.S. CONST. art. I, § 8, cl. 3.

195. Sturm, supra note 169 , at $74,75-76$ tbl.3.

196. Rodriguez, supra note 87, at 277 ("State constitutions are documents of limits, while the federal constitution is a document of grant."); Williams, supra note 177, at 178 (“State constitutions are usually contrasted with their federal counterpart by characterizing the former as limits on governmental power rather than grants of power.”).

197. Linde, supra note 5, at 182 (noting that by 1984, eleven states had specific constitutional privacy guarantees). 
"fundamental" would need to look not only to states' due process jurisprudence, but also to other provisions in their constitutions. In other words, state constitutional rights that lack federal analogues are not necessarily irrelevant. They may simply be evidence of the kinds of rights that the Supreme Court should recognize as unenumerated in the federal Constitution.

Finally and relatedly, state constitutional doctrine is hardly uniform, so for many legal questions it may be impossible to identify "what state constitutional law says" about a particular issue. Obviously, whenever this is the case, the Supreme Court need not defer to an imagined plurality or unanimity of state practice. And yet state constitutional doctrine does tend to converge over time, in part because state courts, in keeping with the common law tradition, tend to borrow doctrine from one another. ${ }^{198}$ The more they agree, the more weight their shared view should receive. ${ }^{199}$

In any event, these objections about differences could be raised about comparativism of any kind. At the very least, states share a constitutional heritage with the nation, have similar constitutional charters, and should therefore be relatively good candidates for comparative study.

b. State Constitutions Are Not Good Enough, or State and Federal Judges Are Not Up to the Task

A somewhat more pointed objection is that state constitutions and state judges are not "good" enough to be useful in federal constitutional interpretation, or that federal judges will find it impossible as a practical matter to divine state constitutional law or employ it in any meaningful way to federal constitutional interpretation.

It has often been argued that state judges are simply not as trustworthy as their federal counterparts when it comes to the protection of constitutional rights, in part because-as Part III.B.2 explains-they are more subject to political pressures. Some version of this argument lies at the heart of the debate associated with Burt Neuborne's article "The Myth of Parity," 200 which was published in the same volume of the Harvard Law

198. Gardner \& Rossi, supra note 60, at 1231 (“A borrowing mentality emerged, as courts looked outside of their jurisdictional territories to state constitutions to fill gaps in constitutional interpretation.").

199. See Gardner, supra note 40, at 1037 ("The more state courts agree among themselves, the more influence their collective position may have upon federal reasoning in cases arising under the U.S. Constitution.").

200. Burt Neuborne, The Myth of Parity, 90 Harv. L. Rev. 1105 (1977). See also Michael E. Solimine, The Future of Parity, 46 WM. \& MARY L. REV. 1457 (2005). 
Review as Justice Brennan's ode to state courts. ${ }^{201}$ Neuborne dismissed the "assumption of parity" between state and federal courts as a "dangerous myth,"202 pointing to state judges' "vulnerab[ility] to majoritarian pressure."203

State constitutional law may be subject to the same criticism. In a controversial but influential article, Gardner described what he called the "Failed Discourse of State Constitutionalism," arguing that a theory of state constitutional interpretation was practically impossible and normatively undesirable. ${ }^{204}$ Daniel Rodriguez adds that "[s]tate constitutional theory remains a rather barren, mundane field, with little substantive controversy, creative thinking, or paradigm-shaking." ${ }^{205}$ And even those who disagree with Gardner's normative conclusions tend to agree with his descriptive diagnosis. ${ }^{206}$ According to Hans A. Linde,

Most state constitutions are dusty stuff-too much detail, too much diversity, too much debris of old tempests in local teapots, too much preoccupation with offices, their composition and administration, and forever with money, money, money. In short, no grand vision, no overarching theory, nothing to tempt a scholar aspiring to national recognition. ${ }^{207}$

Coming from a former state supreme court justice who supports a robust system of state constitutional law, this is quite an indictment.

Moreover, just as state judges may be disfavored when it comes to protecting constitutional rights and articulating a constitutional vision, federal judges may be incompetent to utilize state law. Federal judges and their law clerks are not likely to be experts in any state's law, even though diversity jurisdiction requires them to utilize it. ${ }^{208}$ And even if federal

201. Brennan, State Constitutions, supra note 6.

202. Neuborne, supra note 200, at 1105.

203. Id. at 1127-28.

204. Gardner, supra note 33. But see Daniel J. Elazar, A Response to Professor Gardner's The Failed Discourse of State Constitutionalism, 24 RUTGERS L.J. 975 (1993) (criticizing Gardner); Schuman, supra note 59 (same).

205. Rodriguez, supra note 87 , at 271.

206. See, e.g., Schuman, supra note 59, at 276 (criticizing Gardner's thesis, but noting that "Gardner is surely correct in his conclusion that state constitutional discourse in most jurisdictions, including the ones he surveys, is impoverished”).

207. Linde, supra note 5, at 196.

208. This is a problem for state judges as well, since their clerks are likely to be more familiar with federal law. Douglas, supra note 60, at 1147 ("The fact that law clerks working for state judges have only been taught or are familiar with federal cases brings a federal bias to the various states as they fan out after graduation from 'federally' oriented law schools.”); Linde, supra note 5 at 177 (“Our law clerks come prepared for nothing else.”). 
judges were inclined to look to state law for guidance, they would find the path to be dimly lit: legal scholarship has largely remained faithful in its monogamist devotion to the federal Constitution.

There are no straightforward answers to these objections. It may very well be the case that some state judges are incompetent, or even that, on average, they are less competent than their federal counterparts. But as a practical matter, it remains true that "under our constitutional structure it is the state, and not the lower federal, courts that constitute our ultimate guarantee that a usurping legislature and executive cannot strip us of our constitutional rights." ${ }^{209}$ If state courts can be trusted alongside federal courts as the ultimate guarantors of constitutional rights, then presumably their efforts to articulate constitutional values are also worthy of respect.

\section{THE APPROACH IN PRACTICE}

\section{A. REVISITING AND ElABORATING THE THESIS: TOWARD A TAXONOMY}

The relative weight of these arguments for and against borrowing state constitutional law varies according to the constitutional question at issue and the interpretive theory one endorses. What is needed, therefore, is a taxonomy of areas for which borrowing is most likely to be appropriate, and some indication of how much weight it should be given. A number of considerations seem relevant.

First, borrowing of state constitutional law is undoubtedly more useful when the states have spoken with a relatively unified voice-when their laboratories have come up with similar results. The standard of review for gun regulations, explored in more detail in Part IV.C, is a particularly striking example in this regard because the states have been nearly unanimous in endorsing a "reasonable regulations" standard of review. And in the three areas of constitutional law described in Part IV.B-criminal procedure, due process, and the Eighth Amendment-the Court has generally employed a kind of head-counting approach that gives more weight to state practice (some of it constitutional) the more widely it is shared. Doing so helps minimize the appearance of federal courts "choosing sides" when state courts disagree about constitutional principles.

Second, state constitutional law should be more relevant to federal interpretation when analogous rights or issues are involved. For example,

209. Paul M. Bator, The State Courts and Federal Constitutional Litigation, 22 WM. \& MARY L. REV. 605, 627 (1981). 
more than thirty states have due process clauses whose wording is identical to the federal clause. ${ }^{210}$ Accordingly, their interpretations of those clauses should presumptively be entitled to more weight than those of states with clauses whose language differs. Depending on one's preferred method of constitutional interpretation, the same could be said about other potentially distinctive characteristics, such as original intents or understandings. But it does not follow that state constitutional law should be relevant only when provisions are clearly analogous. As Part IV.D argues, state practice may be relevant to federal constitutional law even when the only "hook" is the federal Due Process Clause.

Third, state constitutional law should be (and is) more properly influential in federal cases in which the federal doctrine itself calls for a survey of state practice. In due process cases, for example, the question is whether a particular right is "fundamental," and state constitutional law provides the answer to the federal inquiry, rather than influencing the question itself. This is not quite the same as relying on state constitutional law as persuasive authority, since it essentially means counting heads instead of evaluating reasoning, but it does suggest a broad and important role for state constitutional law.

Fourth, state constitutional law is particularly useful when federal courts lack necessary "practical" experience. Again, regulation of the "individual” right to keep and bear arms provides a useful example because it is a right that the states have recognized (and regulated) for far longer than the federal government. Accordingly, federal courts can limit their speculation about the particular consequences of a particular standard of review or legal rule by simply looking to its impact at the state level.

Assuming that there is a valid "state" position on a constitutional issue, the next major question is how much weight that position should be accorded. That question can be answered in many ways, just as state courts have developed many different methods for taking federal constitutional law into account. At one end of the spectrum, one could imagine a system in which state constitutional law defines federal law. For example, if state courts have unanimously decided that pornography is not protected in their own constitutions, then the federal courts might be compelled (absent some extraordinary reason to the contrary) to follow suit in First Amendment doctrine. Or, as described in Part IV.B.3, if states are nearly unanimous in finding a particular punishment unconstitutional, then it could follow naturally that the Eighth Amendment prohibits the punishment as well.

210. Gardner, supra note 40, at 1029. 
This approach would take the notion of "reverse incorporation" quite seriously-incorporation, after all, applies federal constitutional rules to the states, rather than simply looking to them as persuasive authority. Relaxing that standard slightly, federal courts might accord the states a presumption of correctness, as state courts sometimes do with regard to the Supreme Court's rulings. ${ }^{211}$ If state courts feel the need to explain their departures from Supreme Court rulings ${ }^{212}$ — which are no more formally binding on state constitutional interpretations than state court interpretations are binding on federal law-then perhaps it stands to reason that the Court should do the same when roles are reversed.

In keeping with the taxonomy sketched out above, these strong versions of reverse incorporation or intranational comparativism may be appropriate in some areas of law but not others. For example, a unanimous state constitutional practice protecting a particular right would be almost definitive evidence that the right is "fundamental" for due process purposes. But such a rigid approach is likely too strong in other areas of law. For example, if state law is relevant only to the degree that it is convincing, then the uncritical adoption of state constitutional law would verge on an inverted version of the justly criticized "lockstep" approach followed by many state courts. In those areas of law, it may be more appropriate for state constitutional doctrine to serve as a kind of persuasive authority, influencing federal courts through the power of its reasoning, ${ }^{213}$ just as federal doctrine may at times persuade state courts. ${ }^{214}$ At the very

211. See, e.g., Gabrielli v. Knickerbocker, 82 P.2d 391, 393 (Cal. 1938) (“[C]ogent reasons must exist before a state court in construing a provision of the state Constitution will depart from the construction placed by the Supreme Court of the United States on a similar provision of the federal Constitution.”); Alan B. Handler, Expounding the State Constitution, 35 RuTGERS L. REV. 202, 204 (1983) (" $[R]$ esort to the state constitution as an independent source for protecting individual rights is most appropriate when supported by sound reasons of state law, policy, or tradition.”).

212. See Developments in the Law, supra note 84, at 1357 ("When a state court diverges from the federal view, a reasoned explanation of the divergence may be necessary if the decision is to command respect."); Friedman, supra note 51, at 109 (“[C]ommentators and jurists contend that state courts should defer to U.S. Supreme Court interpretations absent some principled basis for distinguishing otherwise textually indistinguishable constitutional provisions.").

213. See Friedman, supra note 51, at 128-30 (describing advantages to robust state court constitutional jurisprudence as "an interpretive counterpoint to ... U.S. Supreme Court" doctrine, as well as contributing to "[p]rudential interests in predictability and stability" in areas in which the Court has had difficulty, such as search and seizure and religious liberty).

214. Gardner, supra note 40, at 1059 ("The likeliest explanation [for why state courts so frequently copy federal constitutional doctrine] is undoubtedly the most obvious one: state judges adopt the Supreme Court's approach because they like it and think that it does a perfectly adequate job of protecting the liberty in question.”). See also State v. Kaluna, 520 P.2d 51, 58 n.6 (Haw. 1974) (holding that an "opinion of the United States Supreme Court... is merely another source of authority, admittedly to be afforded respectful consideration, but which we are free to accept or reject in 
least, "whenever a state court dissents from the reasoning of a U.S. Supreme Court decision, it offers a forceful and very public critique of the national ruling, which can in the long run influence the formation of public and, eventually, official opinion on the propriety of the federal ruling."215 Over time, the power of these state court decisions may have an impact on federal doctrine. ${ }^{216}$ In that way, a state court decision is somewhat akin to a dissent in a federal case ${ }^{217}$ - it is not binding, but articulates a reasoning that other courts may find convincing.

There is yet another way in which state constitutional law can be useful, even if it is not strictly binding. Some federal constitutional doctrines require the Court to identify constitutional values-for example, what rights are "deeply rooted in this nation's history and tradition" as evidenced by “[o]ur Nation's history, legal traditions, and practices," ${ }^{218}$ or what punishments violate "the evolving standards of decency that mark the progress of a maturing society." ${ }^{219}$ In answering these inquiries, state constitutional law can be important not because it is binding or persuasive, but because it provides the answer to the question that federal doctrine asks. In these scenarios, state constitutional law is itself the object of study. Thus, where federal doctrine asks whether a right is "deeply rooted in this nation's history and tradition," the relevant evidence may be whether it is-not why it is.

Drawing a line between adopting questions and adopting answers highlights another important distinction: that between tests and conclusions, or reasoning and holdings. ${ }^{220}$ As noted above, state courts seem perfectly comfortable borrowing the former from federal law. ${ }^{221}$

establishing the outer limits of protection afforded by ... the Hawaii Constitution”); State v. Hempele, 576 A.2d 793, 800 (N.J. 1990) ("In interpreting the New Jersey Constitution, we look for direction to the United States Supreme Court, whose opinions can provide 'valuable sources of wisdom for us."” (quoting State v. Hunt, 450 A.2d 952, 960 (N.J. 1982) (Pashman, J., concurring))).

215. Gardner, supra note 40, at 1033.

216. See Edmund B. Spaeth, Jr., Toward a New Partnership: The Future Relationship of Federal and State Constitutional Law, 49 U. PITT. L. REv. 729, 742 (1988) (arguing that federal decisions, to be fully persuasive, should take into account state court reactions to their prior decisionmaking).

217. Gardner, supra note 33, at 831 ("The idea of dissenting opinions furnishes a useful model for thinking about state constitutional variations.").

218. Washington v. Glucksberg, 521 U.S. 702, 720-21 (1997) (citations and internal quotation marks omitted).

219. Trop v. Dulles, 356 U.S. 86, 100-01 (1958) (plurality opinion).

220. Linde, supra note 65, at 929 (noting cases in which a state court "agrees with the Supreme Court's result but rejects 'balancing,' more or less 'fundamental' rights, 'degrees of scrutiny,' or other Supreme Court clichés of the times”).

221. Id. at 951 ("In short, state courts seem content to copy whatever judicial formulas are in fashion, especially elastic formulas that let the court reach its own decision on the merits, for which the 
Indeed, state courts have often been criticized for using the Supreme Court's "verbal formulas." 222 But even when state courts borrow the Supreme Court's "questions" (its constitutional tests and standards), they need not—and do not-answer them the same way. It may be, for example, that state constitutional law gives more or less weight to a particular government interest than federal law does, or that the interest at issue (public safety, for example) means more to states than it does to the federal government. ${ }^{223}$ As Louis Bilionis has noted, "the constitutionally significant facts may be different at the state and federal levels .... Indeed, whenever a constitutional methodology admits a need to accommodate institutional considerations, the possibility for different yet equally correct state and federal results exists." 224 In other words, even if the equations are the same, the variables — and therefore results—may not be.

There are also other, more nuanced ways to take state constitutional principles into account. One is to acknowledge different standards, under federal law, for state and federal action ${ }^{225}$-for example, requiring federal gun control to satisfy strict scrutiny, but holding state gun laws to reasonableness review. The possibility of varying standards was bandied about during the incorporation debate, ${ }^{226}$ and various Justices have

Supreme Court's current formulas are eminently suited.”).

222. Jennifer Friesen, State Courts as Sources of Constitutional Law: How to Become Independently Wealthy, 72 NOTRE DAME L. REV. 1065, 1067 (1997) ("I want to question the uncritical adoption, when giving meaning to state constitutional rights, of verbal formulas that the United States Supreme Court uses to measure federal constitutional rights or powers."); Gardner, supra note 33, at 766 (noting that states have "borrowed wholesale from federal constitutional discourse, as though the language of federal constitutional law were some sort of lingua franca of constitutional argument generally”); Linde, supra note 65, at 943 (“Adopting timeworn verbiage in applying similar constitutional clauses is a venial sin ....”).

223. Cf. Linde, supra note 65, at 932 ("The diversity that the Constitution allows the states undercuts these formulas because it leaves state legislatures free to give strong protection to a right that the Court does not consider 'fundamental' and to disown a governmental interest that the Court has found 'compelling.'”); Williams, State Courts, supra note 184, at 1514 (describing state court adoption of Supreme Court tests as a weaker form of lockstepping).

224. Robert F. Williams, In the Glare of the Supreme Court: Continuing Methodology and Legitimacy Problems in Independent State Constitutional Rights Adjudication, 72 NoTRE DAME L. REV. 1015, 1053 (1997) (quoting Louis D. Bilionis, On the Significance of Constitutional Spirit, 70 N.C. L. REV. 1803, 1808-09 (1992)).

225. Mark D. Rosen, The Surprisingly Strong Case for Tailoring Constitutional Principles, 153 U. PA. L. REV. 1513, 1516 (2005) (noting that "today's doctrine virtually always utilizes what might be called a categorical 'One-Size-Fits-All' approach to those constitutional principles that apply to more than one level of government" but arguing that this approach "is problematic because the different levels of government-federal, state, and local—sometimes are sufficiently different that a given constitutional principle may apply differently to each level").

226. See generally Louis Henkin, "Selective Incorporation" in the Fourteenth Amendment, 73 YALE L.J. 74 (1963) (suggesting standards for selective incorporation of the federal Bill of Rights 
acknowledged it over the years. ${ }^{227}$ In some limited circumstances, the Court has embraced such differential standards. For a few years, states were held to a higher standard than the federal government with regard to affirmative action, for example. ${ }^{228}$ And in Apodaca v. Oregon, ${ }^{229}$ the Court held that a state jury's verdict need not be unanimous in order to support a criminal conviction, despite the fact that federal juries must be. ${ }^{230}$ And yet, as Justice Harlan pointed out in his dissent in Baldwin v. New York, fortyseven states already required unanimity for felony convictions under their own constitutions. ${ }^{231}$

The thesis that federal courts should more often rely on analogous state law is anything but a radical normative claim, which makes it somewhat mysterious that it is so inaccurate as a descriptive one. One explanation might be that federal courts have diagnosed and are attempting quietly to treat our "national neurosis" about federalism ${ }^{232}$ by-at least in this small way-refusing to pay homage to the inflated importance of state identity. Despite some state judges' insistence on state-specific constitutionalism, ${ }^{233}$ critics have argued that such positivism is impossible to maintain, since states are neither culturally unique nor legally autonomous. Paul Kahn, for example, argues that

[t]o rest state constitutionalism on an idea of the state as an alreadydefined historical community, with a text that can be interpreted to reflect the unique political identity of members of that community, is to try to build a serious legal doctrine on what may be no more than an anachronism or romantic myth. ${ }^{234}$

against the states).

227. See, e.g., McDonald v. City of Chicago, 130 S. Ct. 3020, 3093-95 (2010) (Stevens, J., dissenting); Gideon v. Wainwright, 372 U.S. 335, 352 (1963) (Harlan, J., concurring); Williams, In the Supreme Court's Shadow, supra note 4, at 395 \& n.212 (citing opinions of Justices Burger, Powell, and Rehnquist).

228. Compare Metro Broad., Inc. v. FCC, 497 U.S. 547, 563-66 (1990) (applying intermediate scrutiny to federal affirmative action measures, but strict scrutiny to state measures), with Adarand Constructors, Inc. v. Peña, 515 U.S. 200, 227-31 (1995) (overruling Metro Broadcasting, Inc. v. FCC and applying strict scrutiny to all race-based affirmative action).

229. Apodaca v. Oregon, 406 U.S. 404, 406 (1972).

230. See Johnson v. Louisiana, 406 U.S. 356, 363 (1972) (noting that federal courts "operate[] under the unanimity rule"). McDonald casts doubt on Apodaca's continuing vitality, but did not specifically overrule it. See McDonald, 130 S. Ct. at 3035 n.14 (plurality opinion).

231. Baldwin v. New York, 399 U.S. 117 app. at 138-43 (1970).

232. See Edward L. Rubin \& Malcolm Feeley, Federalism: Some Notes on a National Neurosis, 41 UCLA L. REV. 903, 905, 950-52 (1994).

233. Roscoe Pound Found., Protecting individual Rights: The Role of State CONSTITUTIONALISM 62 (Barbara Wolfson ed., 1993) (referring to state judges' "vigorous[] reject[ion]" of the "call to turn away from unique state sources").

234. Kahn, supra note 75, at 1160. 
Thus, any efforts to craft state constitutional law based on state identities is doomed to fail. In other words, the constitutional values that matter-in both state and federal cases-are national ones. ${ }^{235}$

But in the course of describing that objection, the strength of the thesis begins to emerge more clearly. For even if states' primacy as sources of political power and identity has faded over time, it does not necessarily follow that state courts are inadequate when it comes to articulating constitutional rights. ${ }^{236}$ State courts, after all, remain charged with the elaboration and enforcement of federal constitutional law, ${ }^{237}$ and, as noted above, they generally have followed federal doctrine even when supposedly applying state constitutional law. ${ }^{238}$ In any event, federal constitutional law already is shaped by the states, since it "often incorporates state law by reference, taking on local hues and molding its shape to fit different and changing state law rules." ${ }^{239}$ Thus, for example, "legitimate expectations of privacy" under the Fourth Amendment are in some sense dependent on background state law regarding property and privacy. ${ }^{240}$ Takings doctrine, too, is a federal rule, but it depends on state law to define what counts as property. When applying these doctrines, federal courts have no choice but to consider state law, constitutional or otherwise.

The more one moves away from the notion of states as separate from the nation, the more useful state courts become as expositors of federal constitutional values. If the lines between state and federal power and law

235. See Gardner, supra note 33, at 828 ("The tension between state and national constitutionalism has been largely resolved in the modern day United States by the collapse of meaningful state identity and the coalescence of a social consensus that fundamental values in this country will be debated and resolved on a national level."); Kahn, supra note 75, at 1166 ("Whatever the differences in historical origins [of the states], those differences are less and less relevant to today's communities.”).

236. Force, supra note 42, at 127 ("Whatever future the states have as viable governmental entities, state and/or local responsibility for protecting individual rights need not be substantially undermined by the two factors cited most for the decline of the states: limited finances and obsolete government structures.”).

237. Bator, supra note 209, at 605 (considering "the role of the state courts in the elaboration of federal constitutional law and the enforcement of federal constitutional principles”).

238. See Johansen, supra note 62, at 317 ("[M]ost state courts have very little to guide their interpretation of the state constitution other than a body of state case law dependent primarily on the United States Constitution.”).

239. Akhil Reed Amar, Foreword, Lord Camden Meets Federalism-Using State Constitutions to Counter Federal Abuses, 27 RUTGERS L.J. 845, 854 (1996).

240. Id. at 860. See also Tennessee v. Garner, 471 U.S. 1, 15-16 (1985) (noting that "[i]n evaluating the reasonableness of police procedures" the Court has "looked to prevailing rules in individual [state] jurisdictions”). 
have blurred, ${ }^{241}$ the proper response is not to ignore state constitutionalism, but to recognize that it is part and parcel of the federal constitutional system. State constitutions themselves "flourish in light of, and not despite, the American constitutional system." ${ }^{42}$ As James A. Gardner puts it, "a state constitution belongs jointly to the polities of both the state and the nation."243 After all, the "American federal system... [is] a single mechanism," of which the states are a part. ${ }^{244}$

State and federal courts are therefore engaged in an interlocking system of interpretation, just as their respective constitutions are parts of an interdependent constitutional structure. The structure of American federalism, in other words, need not be one that simply divides and separates judicial power. It can instead be one in which various interpretive bodies, both state and federal, are engaged in a shared enterprise of articulating constitutional values. ${ }^{245}$ To a certain extent, jurisdictional rules can encourage this kind of dialogue. ${ }^{246}$ But as an interpretive matter, the conversation between courts must also include something a bit more subtle—not just respecting each other's space, but learning from each other's experience.

\section{B. PRACTical ApPlications}

Having described the arguments for and against the use of state constitutional law in federal cases, and sketched a possible taxonomy for areas in which it may be appropriate, the thesis can be tested against actual constitutional practice.

As noted above, federal courts have never used-and still do not

241. Gardner, supra note 153, at 1256-59. See also Robert A. Schapiro, Justice Stevens's Theory of Interactive Federalism, 74 FORDHAM L. REV. 2133, 2141 (2006) (describing a theory of "interactive federalism" that "rejects the three key elements of dualism," because it "does not seek to draw boundaries between state and federal power[,] ... does not prohibit the national government from coordinating state and federal claims," and "does not conceive of states as distinctive communities of value").

242. Rodriguez, supra note 87, at 289.

243. Gardner, supra note 153, at 1254.

244. Morton Grodzins, The American System: A New VieW of Government in the United STATES 14 (Daniel J. Elazar ed., 1966). See also Elazar, supra note 204, at 976 (arguing that federalism does not presuppose a hierarchy in which states are inferior).

245. Kahn, supra note 75, at 1148 ("The diversity of state courts is best understood as a diversity of interpretive bodies, not as a multiplicity of representatives of distinct sovereigns.").

246. Robert M. Cover \& T. Alexander Aleinikoff, Dialectical Federalism: Habeas Corpus and the Court, 86 YALE L.J. 1035, 1036 (1977) (describing the Warren Court's habeas jurisprudence as "structur[ing] a dialogue on the future of constitutional requirements in criminal law in which state and federal courts were required both to speak and listen as equals”). 
use-state constitutional doctrine to nearly the same degree as state courts have used federal doctrine. There are, however, some notable exceptions to the general history of neglect. ${ }^{247}$ In New York Times $v$. Sullivan, ${ }^{248}$ for example, the Court specifically modeled the actual malice test on "a like rule, which has been adopted by a number of state courts." ${ }^{449}$ And although headcounting is difficult, it seems that around the turn of the century, when state courts were populated by giants like Benjamin Cardozo and Oliver Wendell Holmes, the Court was more likely to take guidance from them. In Davis v. Massachusetts, ${ }^{250}$ for example, the Justices not only deferred to the decision of the Supreme Judicial Court of Massachusetts that was being appealed $^{251}$ —an opinion authored by Holmes_-but also relied on other decisions of that court penned by their future colleague. ${ }^{252}$ Notably, the current Court is the first in history with no Justices who have ever served on a state court.

The following subsections consider three areas in which state constitutional law has had the most influence on modern federal doctrine: criminal procedure, due process, and the Eighth Amendment. Together, these examples both illustrate the arguments discussed in Part III and confirm the taxonomy suggested in Part IV.A. Broadly, the Court's reliance on state constitutional law in the criminal procedure context reflects a pragmatic form of learning from the states' experience and growing unanimity about such practical matters as whether the exclusionary rule deters unconstitutional searches. This is essentially persuasive authority. In the due process and Eighth Amendment contexts, by contrast, the Court has looked to widely shared state practice as "objective" evidence of whether a particular right is fundamental or a particular punishment is cruel or unusual. These are more akin to a strict version of reverse incorporationusing state constitutional law to define federal standard doctrine.

247. Holland, supra note 23, at 998 ("State court decisions shaped federal law in the areas of judicial review, substantive due process, freedom of speech, religion, eminent domain, the right to bear arms, and the rights of the accused.”). See also Friesen, supra note 81, at 28 \& n.12 (discussing examples of state constitutional law influence on Supreme Court decisions).

248. N.Y. Times Co. v. Sullivan, 376 U.S. 254 (1964).

249. Id. at 280 (citing, inter alia, Coleman v. MacLennan, 98 P. 281 (Kan. 1908)). See also THE FirST AMENDMENT RECONSIDERED 43 (Bill F. Chamberlin \& Charlene J. Brown eds., 1982) (“[S]tate courts played an important role in laying the foundations for a modern-day understanding of freedom of speech and of the press.”); Deckle McLean, Origins of the Actual Malice Test, 62 JouRNALISM Q. 750, 751-52 (1985) (tracing the test from Sullivan back to Kansas Supreme Court decisions).

250. Davis v. Massachusetts, 167 U.S. 43, 46-47 (1897).

251. Commonwealth v. Davis, 39 N.E. 113 (Mass. 1895).

252. Davis, 167 U.S. at 47 (citing Lincoln v. City of Bos., 20 N.E. 329, 330 (Mass. 1889) (Holmes, J.)). 


\section{Criminal Procedure}

State constitutional law has had a direct influence on the Court's criminal procedure jurisprudence. Two examples in particular stand out: the exclusionary rule and the right to counsel. Both demonstrate a cooperative constitutional dialogue between the state and federal courts. ${ }^{253}$

The exclusionary rule itself is generally thought to be a federal invention. When the Supreme Court first employed it in 1914's Weeks $v$. United States, ${ }^{254}$ few state courts had yet done so under their own constitutions or constitutional law. ${ }^{255}$ And Weeks, which predated the Court's modern incorporation doctrine, applied the rule only against federal officials. Initially, in Wolf $v$. Colorado, the Court decided not to incorporate the rule against the states. ${ }^{256}$ But by that time, at least sixteen state courts had followed the reasoning of Weeks and interpreted their state constitutions to require the exclusionary rule. ${ }^{257}$ And just twelve years after Wolf, in Mapp v. Ohio, the Court reversed course and decided to incorporate the rule after all. ${ }^{258}$ In doing so, it explicitly relied on the states' independent embrace of the exclusionary rule. ${ }^{259}$ It noted that when Wolf

253. Other examples exist. See, e.g., Benton v. Maryland, 395 U.S. 784, 795 (1969) ("Today, every State incorporates some form of the prohibition [on double jeopardy] in its constitution or common law.”).

254. Weeks v. United States, 232 U.S. 383, 398 (1914).

255. See Force, supra note 42, at 148 ("Weeks was a precedent shattering case; neither federal nor state courts which had followed the common law approach until then had anything else to rely on.”). Robert Force slightly misses the mark with regard to state law, however. It seems that at least a handful of states excluded unconstitutionally obtained evidence even before Weeks. See, e.g., State v. Sheridan, 96 N.W. 730, 730-31 (Iowa 1903) (finding evidence obtained with an improper warrant inadmissible); State v. Height, 91 N.W. 935, 938-40 (Iowa 1902) (finding evidence obtained during a compelled physical examination inadmissible); State v. Newcomb, 119 S.W. 405, 409 (Mo. 1909) (finding compelled examination evidence inadmissible); People v. McCoy, 45 How. Pr. 216, $217-18$ (N.Y. Sup. Ct. 1873) (same).

256. Wolf v. Colorado, 338 U.S. 25, 33 (1949).

257. Id. app. at 33-38 (listing sixteen states as following the Weeks rule and thirty-one as having rejected it). See also Randall T. Shepard, In a Federal Case, Is the State Constitution Something Important or Just Another Piece of Paper?, 46 WM. \& MARY L. REV. 1437, 1448 n.54 (2005) ("[T]he heretical influence of [Weeks] spread, and evoked a contagion of sentimentality in some of the State Courts, inducing them to break loose from long-settled fundamentals." (quoting 4 JOHN HENRY Wigmore, A TrEatise on THE ANGLO-AMERICAN SySTEM OF EVIDENCE IN TRIALS AT COMMON LAW $\S 2184$, at 633 (2d ed. 1923))).

258. Mapp v. Ohio, 367 U.S. 643, 660 (1961).

259. Gardner, supra note 40, at 1039 (“[T]he Court was deeply influenced by an emerging consensus among state courts, which it carefully and extensively documented, that suppression of illegally seized evidence was the most effective way to deter constitutionally unreasonable searches.”). Whether the states' embrace of the exclusionary rule was truly "independent" is harder to say. It is entirely possible that by announcing the rule in Weeks, the Court influenced the states and thereby helped manufacture the majority it later found relevant. 
was decided in 1949, "almost two-thirds of the States were opposed to the use of the exclusionary rule," ${ }^{260}$ but that by the time of Mapp in 1961, "more than half of those since passing upon it, by their own legislative or judicial decision, have wholly or partly adopted or adhered" to it. ${ }^{261}$ The Court especially emphasized the ruling of the California Supreme Court in People v. Cahan, ${ }^{262}$ which concluded that the exclusionary rule was the only remedy that could ensure compliance with constitutional guarantees. ${ }^{263}$ The Court therefore relied on the states not just as independent expositors of constitutional values, but as laboratories whose practical experience with constitutional rules was enlightening. Notably, Justice Clark's opinion for the Court in Mapp also specifically addressed then-Judge Cardozo's rejection of the exclusionary rule in New York, ${ }^{264}$ saying that "the force of [Cardozo's] reasoning has been largely vitiated by later decisions of this Court."265 That the Mapp majority felt it appropriate to respond to the contrary reasoning of a state court is notable, if only to demonstrate how a state judge with Cardozo's standing and influence can command respect.

The state-federal constitutional dialogue about the exclusionary rule has continued, though increasingly it seems that only state courts are listening. The Court has progressively limited the reach of the exclusionary rule since incorporating it against the states in Mapp. In United States v. Leon, ${ }^{266}$ for example, the Court held that the purpose of the exclusionary rule was to deter future police misconduct, ${ }^{267}$ and that it therefore should not apply in cases in which police officers rely on a warrant they believe in good faith to be valid. ${ }^{268}$ At least twenty state courts, however, have rejected both the deterrence rationale and the good faith exception. ${ }^{269}$ Perhaps the Court will revisit Leon's reasoning and rule if that number reaches the fifty percent figure that seemed so significant in Mapp.

State constitutional law has also been influential in the Court's right to

260. Mapp, 367 U.S. at 651.

261. Id. See also Elkins v. United States, 364 U.S. 206 app. at 224-25 (1960) (noting that twentysix states had voluntarily adopted the exclusionary rule by 1960).

262. Mapp, 367 U.S. at 651.

263. See People v. Cahan, 282 P.2d 905, 911-12 (Cal. 1955).

264. Mapp, 367 U.S. at 653.

265. Id. (referring to Cardozo's opinion in People v. Defore, 150 N.E. 585 (N.Y. 1926)).

266. United States v. Leon, 468 U.S. 897 (1984).

267. Id. at 906 (quoting United States v. Calandra, 414 U.S. 338, 348 (1974))

268. Leon, 468 U.S. at 919 (quoting United States v. Peltier, 422 U.S. 531, 539 (1975)).

269. Friesen, supra note 222, at 1080. See generally Leigh A. Morrissey, Note, State Courts Reject Leon on State Constitutional Grounds: A Defense of Reactive Rulings, 47 VAND. L. REV. 917 (1994) (examining state courts' rejection of the good faith exception). 
counsel jurisprudence. In Johnson v. Zerbst, ${ }^{270}$ the Court held that indigent defendants had a right to appointed counsel in federal prosecutions. Zerbst, in turn, quoted and relied on the Court's earlier decision in Patton v. United States $^{271}$ :

Consistently with the wise policy of the Sixth Amendment and other parts of our fundamental charter, this Court has pointed to "... the humane policy of the modern criminal law ..." which now provides that a defendant ". . . if he be poor, ... may have counsel furnished him by the state... not infrequently.... more able than the attorney for the state."272

But Patton, in turn, was quoting from the Wisconsin Supreme Court decision in Hack v. State. ${ }^{273}$ The state court's reasoning had thereby become part of the federal rule. And it was not simply the state court's language that influenced the Supreme Court. Thirty years after Zerbst, Yale Kamisar noted that when in 1938 the Court held that the right of the accused "to have the assistance of counsel for his defense" provided by the Sixth Amendment included the right of indigents to be furnished counsel, thirty states already afforded counsel as of right to all indigent felony defendants. ${ }^{274}$ Robert Force concludes, "It was the states' approach to the accuseds' rights which supplied the strongest support for the Supreme Court's rationale in Patton v. United States, which in turn, provided the major authority for the decision in Johnson v. Zerbst." ${ }^{\text {275 }}$

There have been other occasions on which federal constitutional rules followed state constitutional rules, albeit not always explicitly. The principle of Batson v. Kentucky, ${ }^{276}$ for example, had already been endorsed by some state courts before the Supreme Court embraced it. ${ }^{277}$ And long before the Court extended Batson's rule to cover preemptory challenges based on gender, ${ }^{278}$ many state courts did as much under their own constitutions. ${ }^{279}$ Similarly, when the Court held that the Sixth Amendment

270. Johnson v. Zerbst, 304 U.S. 458, 462-63 (1938).

271. Patton v. United States, 281 U.S. 276 (1930).

272. Zerbst, 304 U.S. at 463 (quoting Patton, 281 U.S. at 308).

273. Hack v. State, 124 N.W. 492, 494 (Wis. 1910).

274. Yale Kamisar, The Right to Counsel and the Fourteenth Amendment: A Dialogue on "The Most Pervasive Right” of an Accused, 30 U. CHI. L. REV. 1, 16-17 (1962) (footnote omitted).

275. Force, supra note 42, at 145.

276. Batson v. Kentucky, 476 U.S. 79, 89 (1986) (prohibiting preemptory challenges in jury selection based on race).

277. See, e.g., People v. Wheeler, 583 P.2d 748, 761-62 (Cal. 1978).

278. See J.E.B. v. Ala. ex rel. T.B., 511 U.S. 127, 128-29 (1994).

279. See, e.g., State v. Levinson, 795 P.2d 845, 849-50 (Haw. 1990); Commonwealth v. Hyatt, 568 N.E.2d 1148, 1150 (Mass. 1991); State v. Gonzales, 808 P.2d 40, 49-50 (N.M. Ct. App. 1991). 
prohibits the exclusion of women from juries, it noted that this conclusion was "consistent with the current judgment of the country, now evidenced by legislative or constitutional provisions in every State and at the federal level qualifying women for jury service.”280

Criminal procedure remains a comparatively rich area of dialogue between state and federal courts. Indeed, in many ways it was the Burger Court's perceived restriction of constitutional criminal procedure rights that first inspired the "New Judicial Federalism." ${ }^{281}$ And there may be a special reason for this, which is that federalism concerns-and concomitant respect for the states' governmental interests-are especially strong in the context of criminal prosecutions. ${ }^{282}$ Perhaps, then, criminal procedure is one of those areas in which the underlying values of reverse incorporationrespect for federalism and state expertise, for example-are particularly salient.

\section{Substantive Due Process and Incorporation}

State constitutional doctrine has played a notable, albeit less direct, role in the Court's substantive due process and incorporation cases. This may not be entirely surprising, since the inquiries in both sets of cases focus on what rights are "fundamental." State constitutional law can serve as uniquely good evidence of what rights meet that standard. ${ }^{283}$

The Supreme Court considered the Due Process Clause only twice between 1789 and $1868 .{ }^{284}$ State courts therefore had an opportunity to define many of the relevant terms—“deprive," "liberty," and "property"before federal courts $\operatorname{did}^{285}$ When the Court eventually embraced the concept of substantive due process and a corresponding protection of

280. Taylor v. Louisiana, 419 U.S. 522, 533 (1975).

281. George R. Moore, Note, Expanding Criminal Procedural Rights Under State Constitutions, 33 WASH. \& LEE L. REV. 909, 915 (1976) (“[A] rapidly increasing number of state courts have declined to follow Supreme Court decisions in the criminal law area, and have established higher standards within their respective states based upon the authority of state constitutions."). See also supra note 77.

282. See, e.g., Gregg v. Georgia, 428 U.S. 153, 176 (1976) ("The deference we owe to the decisions of the state legislatures under our federal system . . . is enhanced where the specification of punishments is concerned, for 'these are peculiarly questions of legislative policy."' (quoting Gore v. United States, 357 U.S. 386, 393 (1958))).

283. See, e.g., Powell v. Alabama, 287 U.S. 45, 73 (1932) (“A rule adopted with such unanimous accord reflects, if it does not establish, the inherent right to have counsel appointed, at least in cases like the present, and lends convincing support to the conclusion we have reached as to the fundamental nature of that right.").

284. Charles Warren, The New "Liberty" Under the Fourteenth Amendment, 39 HARV. L. REV. 431, 441 (1926).

285. Id. 
unenumerated rights, its definition of those rights depended on whether the right was a "fundamental principle[] of liberty and justice"286 or "implicit in the concept of ordered liberty." 287 The question essentially boiled down to whether there was a tradition protecting the right, ${ }^{288}$ an inquiry for which state constitutional law-and the states' longer tradition of due process jurisprudence-has proven particularly useful.

The Supreme Court's sexual privacy decisions are illuminating examples. In Bowers v. Hardwick, ${ }^{289}$ the Court upheld a Georgia statute criminalizing sodomy. In doing so, the Court relied heavily on a history of state regulation (implicit evidence that the states did not recognize a constitutional right to sodomy), noting that before 1961 "all 50 States outlawed sodomy, and today, 24 States and the District of Columbia continue to provide criminal penalties for sodomy performed in private and between consenting adults." ${ }^{290}$ After Bowers, however, state courts, relying on their own state constitutions, began "to extend the protection the Supreme Court withheld."291 In 1998, the Georgia Supreme Court itself specifically rejected the Bowers rule, holding the very same sodomy statute unconstitutional under the state's Due Process Clause. ${ }^{292}$ The Georgia court noted that it was not bound to interpret that clause in parallel with the Supreme Court's (concededly final) interpretation of the federal Due Process Clause, despite the fact that the two clauses were nearly identically worded. ${ }^{293}$ The Georgia Supreme Court was not the only state court to reject the Bowers reasoning. ${ }^{294}$ Interestingly, the Texas Court of Appeals was among this group, striking down Texas’s ban on same-sex sodomy. ${ }^{295}$

286. Palko v. Connecticut, 302 U.S. 319, 328 (1937) (quoting Hebert v. Louisiana, 272 U.S. 312, 316 (1926)).

287. Id. at 325 .

288. Washington v. Glucksberg, 521 U.S. 702, 710-19, 723 (1997) (reviewing state law and concluding "we are confronted with a consistent and almost universal tradition that has long rejected the asserted right, and continues explicitly to reject it today”).

289. Bowers v. Hardwick, 478 U.S. 186, 196 (1986).

290. Id. at 193-94.

291. Ann Althouse, Federalism, Untamed, 47 VAND. L. REV. 1207, 1219 (1994).

292. Powell v. State, 510 S.E.2d 18, 24-26 (Ga. 1998).

293. Id. at 22 ("[T] 'right to be let alone' guaranteed by the Georgia Constitution is far more extensive than the right of privacy protected by the U.S. Constitution . . ..”). Compare GA. ConsT. art. I, § 1, ๆ I ("No person shall be deprived of life, liberty, or property except by due process of law.”), with U.S. CONST. amend. V ("No person shall ... be deprived of life, liberty, or property, without due process of law ....”).

294. See People v. Onofre, 415 N.E.2d 936, 940-41 (N.Y. 1980); Commonwealth v. Bonadio, 415 A.2d 47, 49-50 (Pa. 1980); supra note 124.

295. State v. Morales, 826 S.W.2d 201, 205 (Tex. App. 1992), rev’d, 869 S.W.2d 941 (Tex. 1994) (striking down Texas Penal Code section 21.06). The Texas Supreme Court reversed and remanded Morales on the grounds that the court of appeals lacked jurisdiction to enjoin enforcement of the statute. 
In Lawrence v. Texas, the Supreme Court overruled Bowers. ${ }^{296}$ It noted that many state courts, construing "provisions in their own state constitutions parallel to the Due Process Clause of the Fourteenth Amendment," ${ }^{297}$ had rejected the Bowers rule. These state court decisions made up a part of the criticism of Bowers that, as the Lawrence Court recognized, had been "substantial and continuing, disapproving of its reasoning in all respects." 298 Thus, as commentators have noted, "It is clear that judicial federalism influenced the Supreme Court's opinion in Lawrence, as the Court found the trend in the states towards decriminalization, a trend largely driven by judicial federalism, worthy of consideration in its federal due process analysis." ${ }^{299}$ Reviewing cases like Lawrence, Gardner concludes that "particularly in the last fifteen years or so, .... the Court has increasingly used the content of state law to provide a baseline against which to measure whether any particular individual right can be considered part of the fundamental liberty protected by the Fourteenth Amendment."300

That question - whether something is a "fundamental liberty protected by the Fourteenth Amendment"-is essentially the same inquiry the Court pursues when deciding whether to incorporate a particular provision of the federal Bill of Rights against the states through the Fourteenth Amendment. Under the Court's selective incorporation jurisprudence, the test is "whether a right is among those 'fundamental principles of liberty and justice which lie at the base of all our civil and political institutions.",301 And even before there was an incorporation doctrine, the Court looked to state constitutional law when determining whether to apply federal rules against the states. In 1833's Barron v. Mayor of Baltimore, for example, the Court concluded that the federal Bill of Rights did not bind the states. ${ }^{302}$ Chief Justice Marshall's opinion for the Court was deeply grounded in state

See State v. Morales, 869 S.W.2d 941, 947-48 (Tex. 1994). This set the stage for Lawrence v. Texas, 539 U.S. 558, 578 (2003), which would invalidate the statute yet again.

296. Lawrence, 539 U.S. at 578-79.

297. Id. at 576 .

298. Id.

299. Fitzpatrick, supra note 34, at 1855.

300. Gardner, supra note 40, at 1040; id. at 1042 ("The U.S. Supreme Court's approach in due process cases arising under the Fourteenth Amendment suggests strongly that state courts have the ability to influence indirectly the content of nationally guaranteed liberties through their rulings under cognate provisions of state constitutions. More to the point, it seems possible for state courts to use this process to work actively, if slowly, to undermine Supreme Court interpretations of the U.S. Constitution with which they disagree.”).

301. Duncan v. Louisiana, 391 U.S. 145, 148 (1968) (quoting Powell v. Alabama, 287 U.S. 45, 67 (1932)).

302. Barron v. Mayor of Balt., 32 U.S. (7 Pet.) 243, 250-51 (1833). 
constitutionalism:

Each state established a constitution for itself, and, in that constitution, provided such limitations and restrictions on the powers of its particular government as its judgment dictated.... In their several constitutions [the states] have imposed such restrictions on their respective governments as their own wisdom suggested; such as they deemed most proper for themselves. It is a subject on which they judge exclusively .... .303

Thus, state constitutional guarantees were originally seen as a reason not to hold states to the terms of the federal document. And even when the Court did eventually incorporate the federal Bill of Rights against the states, it occasionally did so with an eye toward state constitutional law. Wolf and Mapp, described above, ${ }^{304}$ are perfect examples- the latter based the decision to incorporate the exclusionary rule against the states on the fact that the states had already embraced it. Interestingly, the plurality opinion in McDonald - the Court's most recent and perhaps highest-profile incorporation case-did not make use of a near-unanimous state constitutional practice protecting the right at issue. Part IV.C discusses McDonald's approach in more detail.

\section{The Eighth Amendment}

The Eighth Amendment's prohibition on "cruel and unusual" punishment has inspired a somewhat distinct constitutional jurisprudence, one which is heavily comparativist and draws on both foreign and state law sources.

International sources have long played a prominent and controversial role in the Court's Eighth Amendment cases. In Trop v. Dulles ${ }^{305}$-perhaps the foundation of the Court's modern Eighth Amendment jurisprudencethe Court established an inquiry that looks to whether a particular punishment violates "the evolving standards of decency that mark the progress of a maturing society."306 That inquiry, the Court has long recognized, can be advanced by looking to sources from other sovereigns, including foreign and international sources. The Trop Court, for example, concluded that denationalization was cruel and unusual, based in part on the fact that "only two countries [out of eighty-four surveyed] ... impose

303. Id. at $247-48$.

304. See supra notes 259-67 and accompanying text.

305. Trop v. Dulles, 356 U.S. 86 (1958) (plurality opinion).

306. Id. at 101. 
denationalization as a penalty for desertion., ${ }^{307}$ In Atkins v. Virginia, ${ }^{308}$ the Court held that the Eighth Amendment prohibited the execution of the mentally retarded, noting that "within the world community, the imposition of the death penalty for crimes committed by mentally retarded offenders is overwhelmingly disapproved."309 And three years later, in Roper $v$. Simmons, ${ }^{310}$ the Court held that the Eighth Amendment also prohibited the execution of juvenile offenders, again citing foreign law. ${ }^{311}$

Other examples of citation to foreign sources are not hard to find in Eighth Amendment cases. ${ }^{312}$ For good or ill, the practice demonstrates the Court's willingness to construct federal constitutional law based in part on the experiences of other sovereigns. But even more important in the search for "objective indicia" is domestic consensus - that is, the practices of the states. Interestingly, the Court has generally looked to state legislatures, not state constitutions, as the most appropriate evidence of moral consensus. ${ }^{313}$ For example, the Court has stated that the "clearest and most reliable objective evidence of contemporary values is the legislation enacted by the country's legislatures." ${ }^{14}$ If state legislative enactments are useful indicators of current social values, then it seems that state constitutions

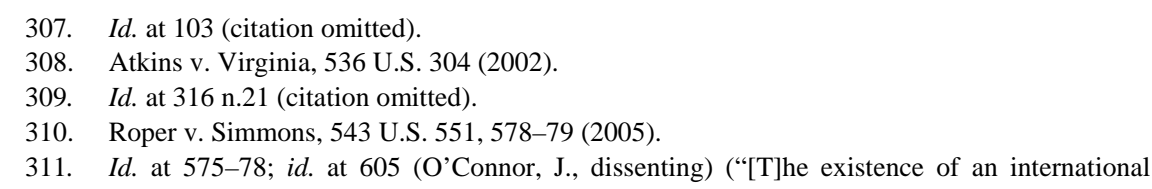
consensus of this nature can serve to confirm the reasonableness of a consonant and genuine American consensus.”). See Comment, The Debate over Foreign Law in Roper v. Simmons, 119 HARV. L. Rev. 103, 103 n.9 (2005) (citing divergent scholarly opinions on the appropriateness and significance of the Court's use of foreign law for constitutional analysis in Roper); Ernest A. Young, Comment, Foreign Law and the Denominator Problem, 119 HARV. L. REV. 148, 153-56 (2005) (arguing that decisions like Roper use foreign law only superficially, as "nose-counting" to increase the denominator and make divergent U.S. law look like "an outlier," but without learning anything persuasive).

312. See, e.g., Roper, 543 U.S. at 604-05 ("This inquiry [into international and foreign law] reflects the special character of the Eighth Amendment, which, as the Court has long held, draws its meaning directly from the maturing values of civilized society.”); Thompson v. Oklahoma, 487 U.S. 815, 830 (1988) (noting that the decision was "consistent with the views that have been expressed by ... other nations that share our Anglo-American heritage, and by the leading members of the Western European community”); Coker v. Georgia, 433 U.S. 584, 596 n.10 (1977) (“It is thus not irrelevant here that out of 60 major nations in the world surveyed in 1965, only 3 retained the death penalty for rape where death did not ensue.”).

313. Hills, supra note 8, at 17 (describing reliance on state law).

314. Penry v. Lynaugh, 492 U.S. 302, 331 (1989). See also Roper, 543 U.S. at 564 ("The beginning point is a review of objective indicia of consensus, as expressed in particular by the enactments of legislatures that have addressed the question.”); Atkins v. Virginia, 536 U.S. 304, 312 (2002) (referring to "the country's legislatures" as the best source of such consensus); Stanford v. Kentucky, 492 U.S. 361, 370 (1989) ("First among the objective indicia that reflect the public attitude toward a given sanction are statutes passed by society’s elected representatives.” (quoting McCleskey v. Kemp, 481 U.S. 279, 300 (1987)) (internal quotation marks omitted)). 
should be as well, especially given the political responsiveness of state constitutions.

\section{The SPeCial EXAmPle OF THE SECOND AMENDMENT}

Perhaps the most important contemporary issue for "reverse incorporation" is the use of state constitutional law in interpreting the newly incorporated Second Amendment. In many ways, the Second Amendment presents the perfect test of the thesis: nearly all state constitutions recognize the "individual" right to keep and bear arms; state constitutional law is well established and remarkably uniform in finding that right to be subject to "reasonable" regulation; federal doctrine is almost nonexistent; and (even holding aside the Amendment's arguably federalism-focused language) gun regulation seems to be an area in which respect for the states' police power and practical experience is particularly important. And yet the plurality opinion in McDonald v. City of Chicago seemed somewhat ambivalent toward contemporary state constitutional law.

For nearly two hundred years, it was widely understood and frequently held that the Second Amendment is essentially a federalism-based provision intended to protect state militia from disarmament by the federal government. ${ }^{315}$ In District of Columbia v. Heller, ${ }^{316}$ however, the Supreme Court held that the Amendment actually protects an "individual" rightthat is, one not necessarily related to militia service-thus inaugurating a new era of Second Amendment jurisprudence. In doing so, the Court did not entirely reject the federalism-based reading of the Amendment, ${ }^{317}$ and it did make explicit use of state constitutional law. ${ }^{318}$ But Heller left open at least two major questions: whether the "individual" right to keep and bear arms should be incorporated against the states, and what standard of review should be used to evaluate restrictions on that right. ${ }^{319}$

315. District of Columbia v. Heller, 554 U.S. 570, 637 (2008) (Stevens, J., dissenting).

316. Id. at 595 (majority opinion).

317. See, e.g., id. at 599 (recognizing that "self-defense had little to do with the right's codification" and "the threat that the new Federal Government would destroy the citizens' militia by taking away their arms was the reason that right—unlike some other English rights—was codified in a written Constitution”). The majority thus apparently endorsed, to some degree, the view taken in United States v. Miller, 307 U.S. 174 (1939), that the Amendment was adopted "[w]ith obvious purpose to assure the continuation and render possible the effectiveness of [militia] forces" and "must be interpreted and applied with that end in view.” Id. at 178.

318. See, e.g., Heller, 554 U.S. at 580 n.6, 583 n.7, 584-85, 590 n.13, 591, 600-04, 612-14, 629.

319. See, e.g., United States v. Booker, 570 F. Supp. 2d 161, 163 (D. Me. 2008) (concluding that the Supreme Court "consciously left the appropriate level of scrutiny for another day"). 
The former question was directly presented and affirmatively answered in McDonald; the latter was indirectly presented and not answered. State constitutional practice would seem to be relevant to both questions, and indeed state law played an interesting role in the various opinions issued by the Justices. The plurality paid little attention to contemporary state constitutional practice, despite the strong support it would have offered for the decision to incorporate. Instead, Justice Alito's opinion took something of an originalist approach, citing only those state constitutions in existence at the Founding ${ }^{320}$ or when the Fourteenth Amendment was ratified. ${ }^{321}$ These were presented as evidence that the individual right to keep and bear arms is fundamental. Similarly, Justice Thomas's concurring opinion cited state constitutional provisions and decisions from the 1800s for the proposition that the right to keep and bear arms is a privilege or immunity protected by the Fourteenth Amendment. ${ }^{322}$

The dissenting opinions took a different lesson from state constitutional law. Justice Stevens noted that "[t]he vast majority of States already recognize a right to keep and bear arms in their own constitutions," 323 but concluded that the answer to the incorporation question "cannot be found in a granular inspection of state constitutions or congressional debates." 324 On the question of incorporation, Justice Stevens pointed to the states' history of "extremely intensive, carefully considered regulation" of gun rights, which, he found, "tend[ed] to suggest that" the right was not "of fundamental character." 325 Justice Breyer also argued against incorporation, but — as he had in Heller - focused on the still-open standard of review question. And as to that question, he (and the three Justices who joined him) endorsed the approach described in this Article, suggesting that "the Court could lessen the difficulty of the mission it has created for itself by adopting a jurisprudential approach similar to the many state courts that administer a state constitutional right to bear arms." ${ }^{326} \mathrm{He}$

320. McDonald v. City of Chicago., 130 S. Ct. 3020, 3037 (2010) (plurality opinion) (referring to "the four States that had adopted Second Amendment analogues before ratification, [and] nine more States [that] adopted state constitutional provisions protecting an individual right to keep and bear arms between 1789 and 1820").

321. Id. at 3042 ("The right to keep and bear arms was also widely protected by state constitutions at the time when the Fourteenth Amendment was ratified.”).

322. Id. at 3079-88 (Thomas, J., concurring).

323. Id. at 3095 n.13 (Stevens, J., dissenting).

324. Id. at 3098.

325. Id. at 3113 n. 43 .

326. Id. at 3127 (Breyer, J., dissenting). See also id. at 3130 (noting that "many States have constitutional provisions protecting gun possession" but that "those provisions typically do no more than guarantee that a gun regulation will be a reasonable police power regulation”); id. at 3134 (“I think 
noted, ruefully, that the Court had declined to do so in Heller and then again in McDonald.

Had the Justices given more weight to contemporary state constitutional law, they might have found something of a middle ground: incorporation of the right, as favored by the plurality and Justice Thomas, but subject to reasonable regulation, as favored by the dissenting Justices (and not ruled out by the other five). Such an approach would have been in keeping both with the Court's prior practice and with the thesis of this Article. As noted above, the Court has often looked to state constitutional practice to determine whether a particular right is "fundamental" and therefore subject to incorporation. In the context of the Second Amendment, this approach counsels in favor of incorporation, because all but a handful of states have constitutional guarantees protecting the right to keep and bear arms, and many of them explicitly protect the "individual" right recognized by the Court in Heller. ${ }^{327}$ As if to drive the point home, thirty-eight states signed an amicus brief in McDonald arguing that the Second Amendment should be incorporated. ${ }^{328}$ The brief was no doubt inspired more by politics than by fear of self-imposed gun regulationafter all, a state's elected officials do not need the Supreme Court to stop them from passing gun regulations-but at the very least it suggests that the states themselves favor the constitutional protection of an "individual" right to keep and bear arms. ${ }^{329}$ Indeed, since nearly all states already protect such a right, the incorporation of the Second Amendment would not necessarily have much of an impact on them.

that it is essential to consider the recent history of the right to bear arms for private self-defense when considering whether the right is 'fundamental.' To that end, many States now provide state constitutional protection for an individual's right to keep and bear arms.”).

327. See Volokh, supra note 21, at 192 (concluding that forty-four states protect an "individual" right, though Virginia and Kansas are equivocal on the matter); Winkler, supra note 22, at 686, 711 (concluding that forty-two states protect an individual right to bear arms).

328. See Brief of the States of Tex. et al. as Amici Curiae in Support of Petitioners, McDonald, 130 S.Ct. 3020 (No. 08-1521), 2009 WL 4378909. Thirty-one states made the same argument in Heller, even though incorporation was not an issue in that case. See Brief of the States of Tex. et al. as Amici Curiae in Support of Respondent at 23 n.6, District of Columbia v. Heller, 554 U.S. 570 (2008) (No. $07-$ 290), 2008 WL 405558 (arguing for incorporation of the right). Wisconsin, a late joiner, added an amicus brief for the respondent arguing in favor of the individual right interpretation, but noting its preference that the Second Amendment not be incorporated against the states. See Brief of the State of Wis. as Amicus Curiae in Support of Respondent at 4-5, Heller, 554 U.S. 570 (No. 07-290), 2008 WL 543032.

329. There is some historical precedent for states requesting that federal constitutional rules be applied to them. In Gideon v. Wainwright, 372 U.S. 335 (1963), twenty-two states asked the Court to overrule Betts v. Brady, 316 U.S. 455 (1942), and require the states to provide counsel in state prosecutions as well. Gideon, 372 U.S. at 345. Three states urged that Betts be left intact. Id. at 345. 
But that raises the second issue left unanswered in Heller: What standard of review should be employed to evaluate Second Amendment claims? If the standard were to be set "higher" than that employed by the states, it would displace their constitutional law just as surely as the Warren Court did with regard to so many other individual rights. But if instead the Court were to look to the states for persuasive authority, it would find that, as with the incorporation question, state constitutional law is remarkably uniform and clear $^{330}$ : every state court to have reached the question has concluded that its state analogue of the Second Amendment permits "reasonable" regulation of firearms. ${ }^{331}$ In other words, along with their long history of recognizing a right to keep and bear arms, states have a "tradition" of limiting that right. ${ }^{332}$ The "fundamental" right that is protected, therefore, is a reasonable right to keep and bear arms. ${ }^{333}$

Nearly every factor discussed above counsels in favor of federal adoption of the states' constitutional rule. ${ }^{334}$ The states' constitutional provisions are similar in content and spirit to the "individual" right-based Second Amendment, which, even after Heller, seems to have something to do with federalism. States have far more experience than the federal government when it comes to charting the lines between gun rights and safety regulation, ${ }^{335}$ and the "reasonableness" standard they have unanimously endorsed both reflects their collective wisdom on the subject and permits individual states to tailor gun regulations to their own circumstances. Indeed, the thirty-one state brief maintained that "[s]tate and local experimentation with reasonable firearms regulations will continue under the Second Amendment."336 The states concluded that "[d]enying local governments the power to nullify the Amendment will not increase federal power, mandate any state action pursuant to federal directives, or preclude reasonable state and local regulation of firearms." 337 The plurality went so far as to quote that passage of the states' brief, claiming that the

330. See supra Part IV.A.

331. Winkler, supra note 22, at 686-87 \& n.12. Winkler has the unusual distinction of being cited by name during a Supreme Court oral argument. Transcript of Oral Argument at 58, McDonald, $130 \mathrm{~S}$. Ct. 3020 (No. 08-1521), 2010 WL 710088.

332. Brief of Thirty-Four Prof'l Historians \& Legal Historians as Amici Curiae in Support of Respondents at 2, McDonald, 130 S. Ct. 3020 (No. 08-1521), 2010 WL 59025.

333. See Adam Winkler, The Reasonable Right to Bear Arms, 17 STAN. L. \& PoL'Y REV. 597, 598 (2006).

334. See supra note 317.

335. See Winkler, supra note 22, at 715-26.

336. Brief of the States of Tex. et al. as Amici Curiae in Support of Petitioners at 23, McDonald, 130 S. Ct. 3020 (No. 08-1521), 2009 WL 4378909 (emphasis added).

337. Id. at 23-24 (emphasis added). 
incorporated Amendment "limits (but by no means eliminates) their ability to devise solutions to social problems that suit local needs and values." 338 But despite quoting the states' use of the word "reasonable," the plurality did not embrace it as a standard, instead reiterating the same categorical carve outs established in Heller. ${ }^{339}$

Because the McDonald court declined to establish a standard of review for Second Amendment claims, it is not too late for the Supreme Court-and other federal courts now faced with the daunting task of evaluating Second Amendment claims with little guidance from the Court - to effectuate respect for state constitutional practice by adopting something like a reasonableness standard. Indeed, the questions and their relationship to state law are deeply intertwined. On the one hand, the states' recognition of a right to keep and bear arms is among the strongest evidence for the argument that the right is "deeply rooted in this Nation's history" and thus subject to incorporation. On the other hand, one must take note of what right the states have recognized: a right that can be reasonably regulated.

\section{OTHER APPLICATIONS}

The "individual" right to keep and bear arms presents an unusual and perhaps uniquely useful test case for the thesis of this Article, given the similarities between the state and federal rights, the remarkable unanimity of state law, and the near absence of relevant federal doctrine.

It may very well be that no other constitutional issue presents quite the same clear-cut opportunity. But given the extensive borrowing that takes place among state courts, and the textual similarities between their constitutions and the federal document, it also seems likely that there are other constitutional questions on which a large majority of state courts have reached similar or identical conclusions. Perhaps most intriguing is the potential influence of those widely recognized state constitutional rights that lack explicit federal analogues. These rights may seem like unlikely candidates for "reverse incorporation," given their dissimilarity from federal guarantees. And yet the federal Due Process Clause could accommodate these rights just as it does others that are not enumerated in the federal document. After all, the Court has incorporated nontextual federal protections against the states, including the "beyond a reasonable

338. McDonald, 130 S. Ct. at 3046.

339. Id. at 3047. 
doubt" standard in criminal prosecutions. ${ }^{340}$ If incorporation can account for these nontextual rights, reverse incorporation should likewise be able to account for rights that are guaranteed at the state level, albeit in provisions that have no direct federal analogues.

Most notable in this regard may be the right to education, which is specifically recognized by forty-nine state constitutions-a convincing majority, if ever there was one-and has often been invoked and enforced by state courts. Of course, the federal Constitution has no such textual guarantee, and the Supreme Court has found that it is not an unenumerated "fundamental" right. ${ }^{341}$ But broadly recognized and accepted state constitutional law suggests that the Court should reconsider. At the very least, if the Court were to confront the question today it would be difficult to hold that a right which is specifically enumerated in forty-nine state constitutions is not "deeply rooted in this Nation's history and tradition,"342 as evidenced by “[o]ur Nation’s history, legal traditions, and practices.”343

\section{CONCLUSION}

There is something unusual about the degree to which federal courts, despite looking to international and scholarly sources for help in constructing constitutional doctrine, have ignored state courts' interpretation of provisions that are deeply intertwined-textually, historically, and legally - with those of the federal charter. Given that state courts are the judicial branch of a coequal sovereign in our federalist system - a system to which the Supreme Court pays frequent homage-it is surprising that they have not been able to catch the Justices' eyes more often. By describing the arguments for and against reliance on state constitutional law in federal constitutional cases, this Article has attempted at the very least to provide a possible and partial explanation for the Justices' negligence.

But there is also a slight normative claim here, which is that state constitutional law should receive more attention from the federal courts than it currently does. This is a slight claim for two reasons. First, since federal courts have heretofore tended to ignore state courts' construction of their own constitutions, it would not take much to amount to "more"

340. In re Winship, 397 U.S. 358, 368 (1970).

341. See San Antonio Indep. Sch. Dist. v. Rodriguez, 411 U.S. 1, 37-38 (1973).

342. Washington v. Glucksberg, 521 U.S. 702, 721 (1997) (quoting Moore v. City of East Cleveland, 431 U.S. 494, 503 (1977) (plurality opinion)).

343. Id. 
attention. Second, it is a slight claim because there are many areas of constitutional law in which the costs of looking to state constitutional law will outweigh the benefits, either because state law is not well developed, not uniform, or is so different that comparison is impossible.

Whatever these areas of law may be, the right to keep and bear arms is not one of them. And so the Article concludes with a sharper critical claim: the Court's failure in McDonald to take into account the states' unanimous, long-held, and well-established constitutional conclusion that the right to keep and bear arms is subject to reasonable regulation was a serious shortcoming. Fortunately, since McDonald declined to set any standard at all, the problem can be corrected by future courts or by the Justices themselves, so long as they are willing to look to state constitutional law, which shaped the federal Constitution at the Founding and could continue to do so today. 